\title{
Article
}

\section{Characterising As-Bi-Co-Cu-bearing minerals at Scar Crags and Dale Head North, Lake District, UK}

\author{
Giulio F.D. Solferino ${ }^{\star \star}$ (D), Nathan T. Westwood ${ }^{1}$, Adam Eskdale ${ }^{1}$ and Sean C. Johnson ${ }^{2}$ \\ ${ }^{1}$ Department of Earth Sciences, Royal Holloway University of London, Egham, Surrey TW20 0EX, United Kingdom; and ${ }^{2}$ iCRAG - Irish Centre for Research in Applied \\ Geosciences, O'Brien Centre for Science, University College Dublin, Belfield, Dublin, Ireland
}

\begin{abstract}
Scar Crags and Dale Head North in the English Lake District host mineralised veins enriched in 'Energy Critical Elements' (ECEs) specifically, bismuth, cobalt and copper. A limited number of studies in the 1970s investigated the mineralogy and inferred the genesis of these veins as being related to the intrusion of the Lake District batholith.

This study investigates the geology, mineralogy, composition and paragenesis of these two mineralised areas. The results highlight the ubiquitous presence of $\mathrm{Co}-\mathrm{Fe}-\mathrm{Ni}$-sulfarsenides in both deposits and the presence of some mineral species, hitherto unreported. Scar Crags samples contained high concentrations of cobalt, commonly present within arsenopyrite, whereas cobalt is of minor importance at Dale Head North, where copper and arsenic are the primary metals. A sequence of events, with As-Co-Ni-bearing fluids infilling the veins after an initial stage of quartz and chlorite precipitation is the most striking resemblance between the two mineralised systems, potentially indicating a common process for Co-rich vein-type deposits in the area. If so, understanding such processes could prove vital in aiding exploration in other terranes.
\end{abstract}

Keywords: Scar Crags, Dale Head North, cobalt mineralisation, As-Bi-Co, ore minerals, energy critical elements

(Received 14 September 2020; revised 3 February 2021; accepted 12 February 2021; Accepted Manuscript published online: 10 March 2021; Associate Editor: Eimear Deady)

\section{Introduction}

Finding primary resources of metals and non-metals classified as critical for our renewable energy future (Energy Critical Elements - ECE) has become a priority for international agencies and organisations (California Institute of Technology, 2011, European Commission, 2020). Energy Critical Elements are essential for the advancement of technology and the development of renewable energy harvesting plants (e.g. manufacture of permanent magnets for wind turbines or production of solar/ photovoltaic cells; California Institute of Technology, 2011). Among the ECE, cobalt is employed in rechargeable batteries for hybrid and electric vehicles, and its worldwide demand is forecast to grow to $\sim 460 \%$ of the current supply by 2030 (Alves et al., 2018). In addition, nearly $70 \%$ of the current supply of cobalt comes from the Democratic Republic of Congo, generating a near-monopoly of production (Alves et al., 2018). The outcomes of recent gatherings of scientists across the disciplines of geosciences and social sciences with representatives of the mining industry and politicians, have presented a number of scenarios. Among those is the exploitation of local, small-scale untapped

\footnotetext{
*Author for correspondence: Giulio F.D. Solferino, Email: dr.zolfo@gmail.com Cite this article: Solferino G.F.D., Westwood N.T., Eskdale A. and Johnson S.C. (2021) Characterising As-Bi-Co-Cu-bearing minerals at Scar Crags and Dale Head North, Lake District, UK. Mineralogical Magazine 85, 197-214. https://doi.org/10.1180/ mgm.2021.22
}

resources, over the next 20-30 years, in contrast to oligopolies (e.g. Department of Energy of the United States of America, 2011; Moss et al., 2011). This outcome implies a necessity for re-evaluation of known metallogenetic areas in Europe, and most of all the need to devise novel metallogenetic models to aid prospectivity of new deposits.

Within this context, the Lake District inlier in England provides a conveniently accessible case study to understand formation processes, main triggers, and specific characteristics of ECE-bearing mineralisation, which could then be used to devise prospectivity indicators applicable to similar terranes worldwide. The present study investigated the As-Bi-Co-Cu mineralisation at two key localities: Scar Crags and Dale Head North, to constrain their paragenesis and style of mineralisation, emplacement history, and to infer the source of mineralising fluids.

\section{Geological context}

The English Lake District inlier is a roughly $50 \mathrm{~km} \times 50 \mathrm{~km}$ region of Cumbria, in north-west England, where the greatest majority of rock outcrops are from the Early-Ordovician (separation of Avalonia from Gondwanaland) to Late-Silurian (collision of Avalonia-Baltica with Laurentia, closure of the Iapetus Ocean) periods, bordered to the north-west, north, east and south by Carboniferous limestones, and to the south-west and south by Permian and Triassic rocks (Bennison and Wright, 1969; Anderton, et al., 1995; Hunter and Easterbrook, 2004, Stone

(C) The Author(s), 2021. Published by Cambridge University Press on behalf of The Mineralogical Society of Great Britain and Ireland. This is an Open Access article, distributed under the terms of the Creative Commons Attribution-NonCommercial-NoDerivatives licence (http://creativecommons.org/licenses/by-nc-nd/4.0/), which permits non-commercial re-use, distribution, and reproduction in any medium, provided the original work is unaltered and is properly cited. The written permission of Cambridge University Press must be obtained for commercial re-use or in order to create a derivative work. 


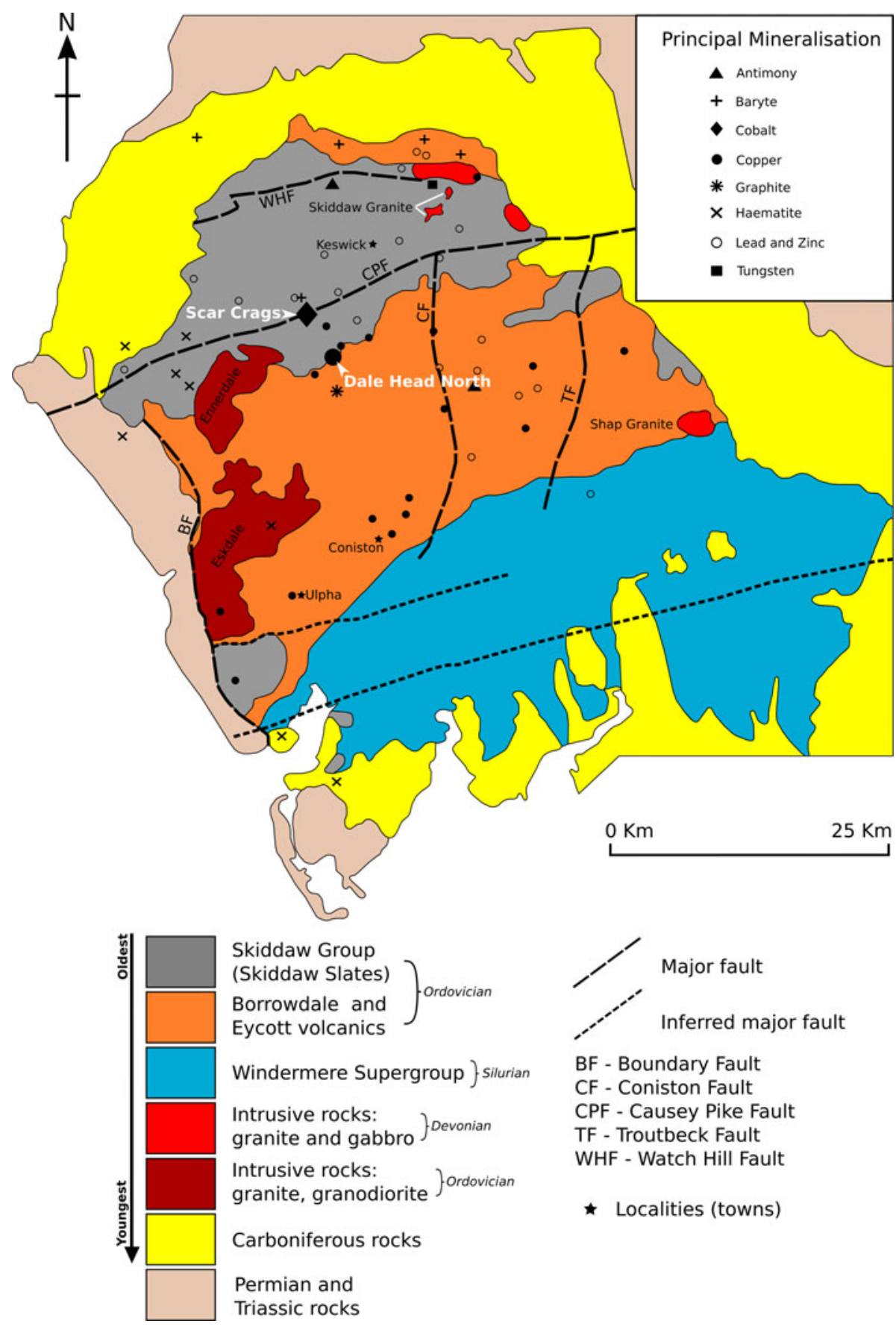

1. Simplified geological map of the Lake District area (UK), including the two studied localities (adapted after Stanley and Vaughan 1982). A high-resolution figure is available in Supplementary materials.

et al., 2010; Fig. 1). A series of intrusive bodies of Late-Silurian and Early-Devonian age, emplaced during the final stage of the Caledonian Orogeny, crops out across this region, with a batholith thought to extend underneath most of the Lake District inlier (Firman and Lee, 1986; Milliward, 2002; Fig. 1). The emplacement of these intrusions caused enhanced circulation of hydrothermal fluids in the overlying Skiddaw Group and Borrowdale Volcanic Group rocks (Cooper et al., 1988).

The lithologies of the Lake District are divided into three main groups: (1) The Skiddaw Group (commonly referred to as Skiddaw Slates); (2) the Borrowdale and Eycott Volcanics (inclusive of the Borrowdale Volcanic Group and the Eycott Volcanic Group), which are Ordovician; and (3) the Windemere
Supergroup (encompassing the Dent Group and the Silurian Shales) formed during the Late Ordovician and the Silurian periods. These three lithostratigraphic units are organised north to south in successive bands trending roughly in a SW to NE direction separated by a series of WSW-ENE thrusts (Fig. 1; Stone et al., 2010).

The Caledonian Orogeny is the dominant geodynamic event that affected the rocks of the Lake District from the Late Ordovician, with a final episode, the Acadian Orogeny (or Acadian phase), that developed during the Early to Mid Devonian period (Stone et al., 2010). The Caledonian orogeny is responsible for the majority of faulting, folding and the very low- to low-grade metamorphism recorded by the rocks of the 


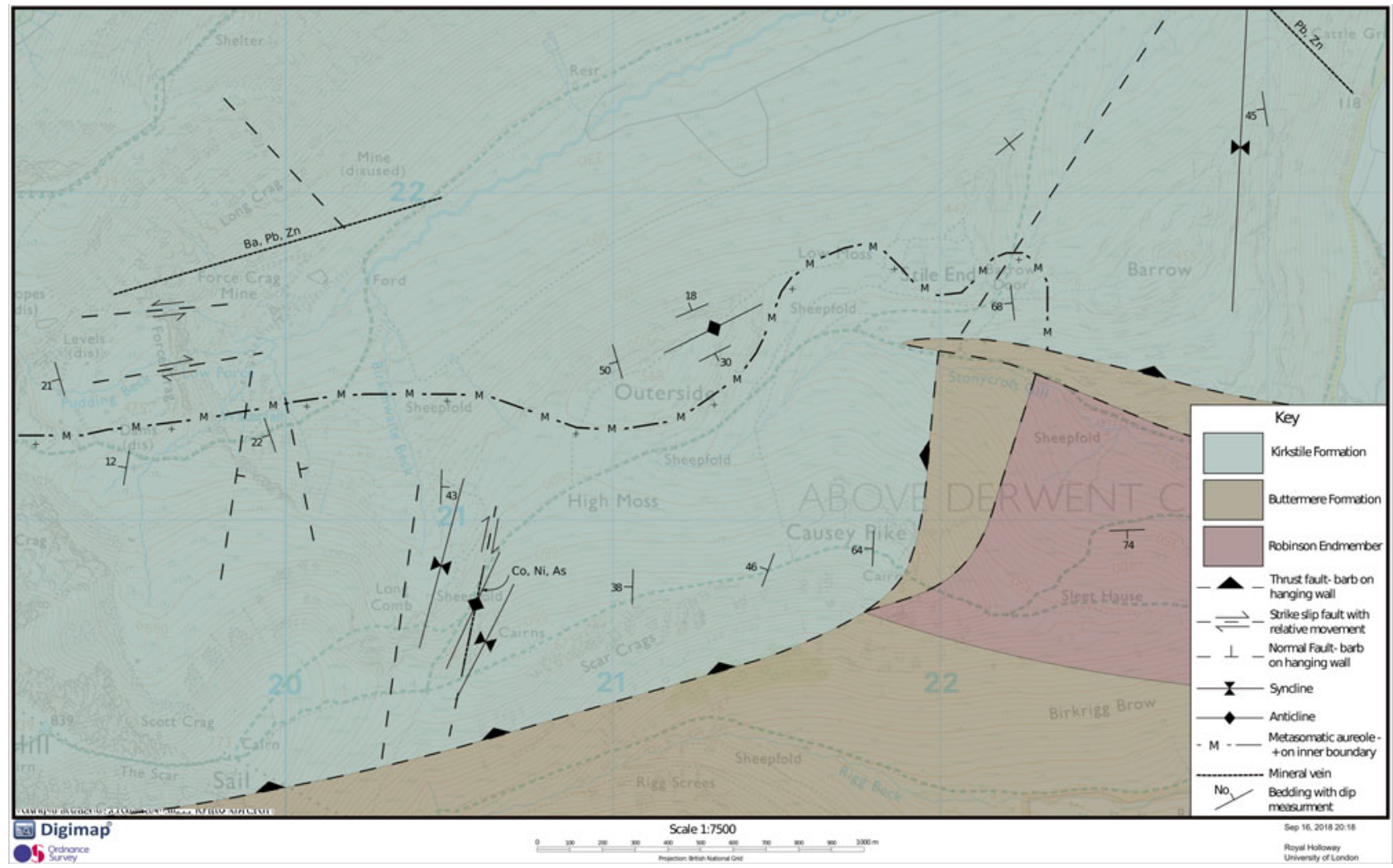

Fig. 2. Detailed geological map of Scar Crags. The main mineralised vein corresponds to a fault plane marked as 'Co, Ni, As' on the map. Formation names from British Geological Survey, 1:50 000 Series, England and Wales Sheet 29, Keswick, Solid Geology. Licensed Data: ( Crown copyright and database rights [2021] Ordnance Survey (100025252). A high-resolution figure is available in Supplementary materials.

Lake District (Dewey, 1969; Mosely, 1978), and it has been considered the main trigger of mineralisation events that occurred in the area by some authors (e.g. Cooper et al., 1988). Of particular relevance for this investigation is the development of a metasomatic aureole, the Crummock Water aureole, caused by the magmatic event also responsible for the emplacement of the Shap and the Skiddaw plutons (Stanley and Vaughan, 1982, Fig. 1; Cooper et al., 1988). The metasomatic event is recorded by a marked change of colour of the affected dark grey siltstone and mudstone, which becomes a bleached pale grey (Cooper et al., 1988).

\section{Mineralisation in the region}

Several episodes of hypogene mineralisation occurred in the region of the Lake District from the Darriwilian to the Hettangian stages, spanning over 200 M.y. Those were triggered by various processes, ranging from favourable tectonics and increased geothermal gradients during the main phases of the Caledonian Orogeny (and to a far lesser extent the Variscan Orogeny), to the intrusion of magma in the deep, or shallower, crust during Late Silurian to Mid Devonian periods (Strens, 1962; Firman and Lee, 1986). Using the principal metal/element in each mineralised region, it is possible to subdivide the Lake District mineral deposits into seven categories (Fig. 1). The metals documented over historic times include $\mathrm{Co}, \mathrm{Cu}, \mathrm{Fe}, \mathrm{Pb}, \mathrm{Sb}, \mathrm{W}$, and $\mathrm{Zn}$ together with graphite. These occur as mineralised veins, skarns, greisens and sedimentary ores. Cobalt, $\mathrm{Cu}, \mathrm{Fe}, \mathrm{Pb}$,
$\mathrm{Sb}$ and $\mathrm{Zn}$ were extracted from sulfides and sulfarsenides during the $19^{\text {th }}$ and $20^{\text {th }}$ Centuries. This study focusses on the vein-type Co-bearing deposits of Scar Crags and Dale Head North. The ore assemblages of these occurrences resemble closely those of one of the four accepted categories of Co ores; i.e. the arsenidesdominant 'five element vein' type (Halls and Stumpfl, 1972; Kissin, 1992; Markl et al., 2016).

It has been assumed that the extensive network of metalliferous veins and occurrences are associated, directly, or indirectly, with the concealed underlying batholith, as they display a close structural relationship to each another (Firman and Lee, 1986; Stone et al., 2010).

\section{Scar Crags}

The mineralised veins of Scar Crags represent the only cobalt mineralisation s.s., as it is the only occurrence in all of the Lake District to host a series of cobalt minerals constituting the bulk of the mineralisation: Co-bearing arsenopyrite; glaucodot $\left(\left(\mathrm{Co}_{0.50} \mathrm{Fe}_{0.50}\right) \mathrm{AsS}\right)$; alloclasite $\left(\mathrm{Co}_{1-x} \mathrm{Fe}_{x} \mathrm{AsS}\right.$, with $\left.x=0.00-0.35\right)$; and cobaltite (CoAsS). Scar Crags veins are hosted within mudstones and siltstones of the Kirkstile Formation (Skiddaw Group) in relative proximity $(5-6 \mathrm{~km})$ to the Borrowdale Volcanic Group rocks (Fig. 2). The veins are hosted by the pale grey 'shales' (mudstones and siltstones - see 'Geological context') that form the Crummock Water metasomatic aureole. 


\section{Dale Head North}

The mineralisation of Dale Head North locality is hosted by rocks of the Buttermere Formation (Skiddaw Group), in close proximity to the boundary with Borrowdale Volcanic Group $(<100 \mathrm{~m}$, Fig. 3). This deposit was included originally in the 'chalcopyrite- pyrite-arsenopyrite type' proposed by Stanley and Vaughan (1982). The Dale Head North vein is unique in the context of copper mineralisation of the Lake District as it contains cobalt minerals, such as Co-bearing pyrite and cobaltite, in contrast to the associated and proximal east-west trending copper veins in the Vale of Newlands (Stanley and Vaughan, 1980).

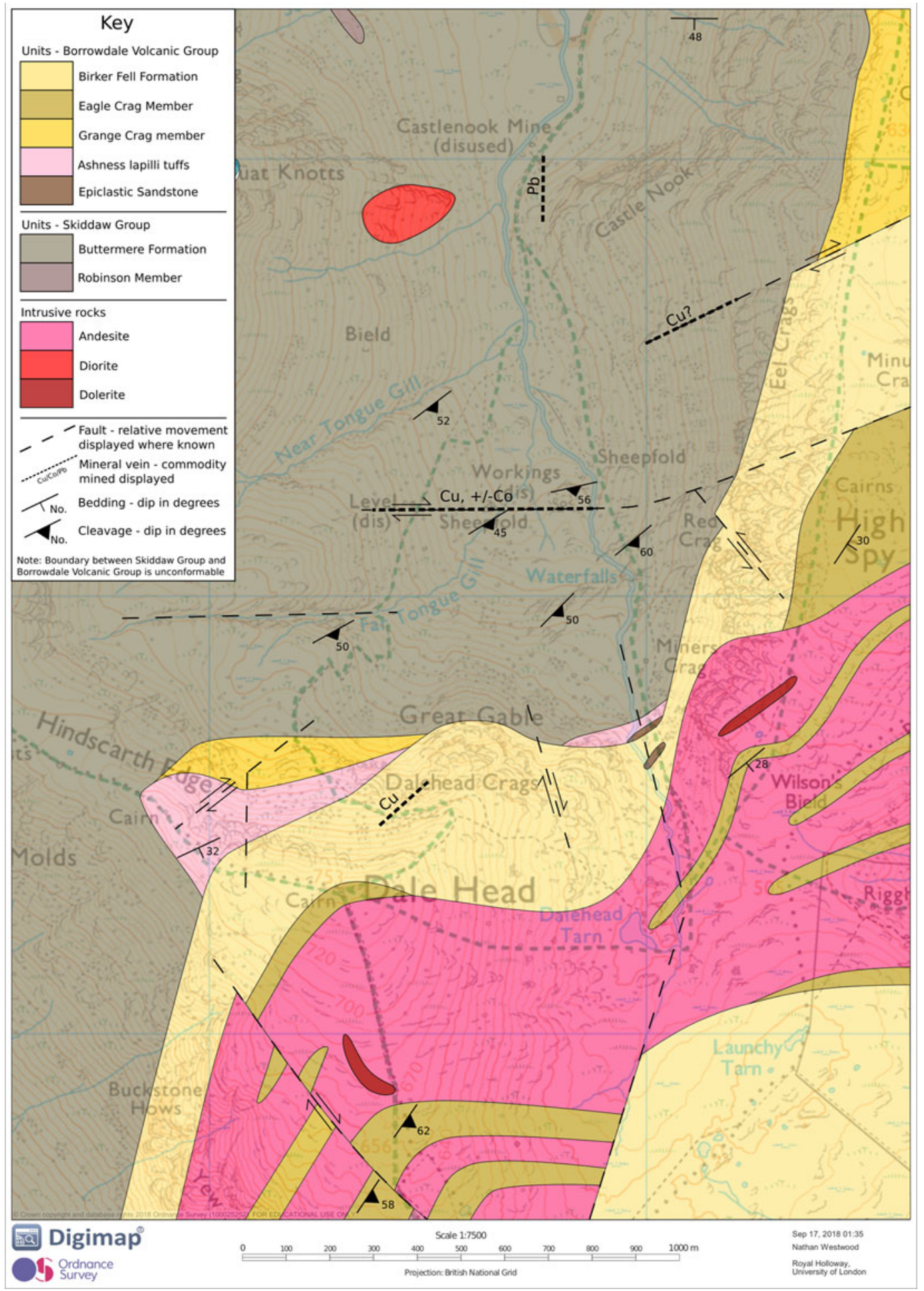

Fig. 3. Detailed geological map of Dale Head North. The main mineralised vein corresponds to a fault plane marked as 'Cu, $+/-\mathrm{Co}$ ' on the map. Formation names from British Geological Survey, 1:50 000 Series, England and Wales Sheet 29, Keswick, Solid Geology. Licensed Data: @ Crown copyright and database rights [2021] Ordnance Survey (100025252). A high-resolution figure is available in Supplementary materials. 


\section{Methods}

The designation of Scar Crags and Dale Head North mineralisation as the target for field study and sampling was based on the reported occurrences of minerals containing Energy Critical Elements, specifically $\mathrm{Bi}$ and significantly Co (Ixer et al., 1979; Stanley and Vaughan 1982).

\section{Fieldwork and sampling}

Geological mapping and structural data were collected on sufficiently broad areas (10.5 and $5.4 \mathrm{~km}^{2}$ for Scar Crags and Dale Head North, respectively) to provide a context to the mineralisation and to allow a comparison with published geological maps at smaller scale (Figs 2 and 3). The majority of samples were taken from mining spoil heaps, fewer were obtained from the least weathered outcrops. At Dale Head North, samples were selected primarily on the basis of the abundance of euhedral pyrite, recognised previously as bearing Co (Stanley and Vaughan 1980).

\section{Remote Sensing}

Analysis of satellite images from various sources including Google Earth $^{\mathrm{TM}}$ [http://www.earth.google.com] and Bing Maps ${ }^{\mathrm{TM}}$ [https:// www.bing.com/maps] was employed to infer lithological changes and structures (e.g. fault planes) when fieldwork provided scarce evidence due to the presence of dense vegetation.

\section{Microscopy and petrography}

Reflected light microscopy was conducted using a Microphot-FX and an Eclipse LV100ND NIKON petrographic microscope. The distinction between various cobalt sulfarsenides proved exceptionally difficult (see section 'Mineralogy and Petrography' in 'Results'), but careful observations on the basis of optical properties and polishing characteristics observed in previous studies (Ixer et al., 1979; Stanley and Vaughan 1980) proved successful and were confirmed by energy dispersive spectroscopy (EDS).

\section{Scanning electron microscopy and energy dispersive spectroscopy}

Scanning electron microscopy (SEM) imaging (normally using back-scattered electron - BSE) and semi-quantitative analysis were carried out with a Hitachi S3000 SEM with an attached Oxford Instrument X-Max $50^{\mathrm{TM}}$ energy-dispersive X-ray spectrometer system. An acceleration voltage of $20 \mathrm{kV}$ was used for the analysis of both ore and non-ore minerals with a probe current of 2-3 nA. Prior to SEM-EDS analysis, all samples were carbon coated. This characterisation work allowed for the identification of extremely minute micro-textural features and to complete the identification of minerals. Furthermore, semiquantitative analysis was employed to refine the sample choice and to devise specific mineral grains as the target of electron microprobe analysis (EMPA).

\section{Electron microprobe analysis}

The primary focus of EMPA was to obtain quantitative compositional analysis of selected samples and to collect high-resolution X-ray elemental maps of key minerals. A JEOL 8200 Superprobe at the Earth Sciences Department of the University of Geneva
(Switzerland) was used with a 1-2 $\mu \mathrm{m}$ focused beam, an acceleration voltage of $20 \mathrm{kV}$ and $20 \mathrm{nA}$ probe current for both ore and silicate minerals. Precision and accuracy were $>1.0 \%$ for all measured elements. Accuracy of measurements was tested by re-analysing the standards every 20 spot analyses, with reproducibility within $99.5 \%$. Precision was computed via multiple analysis of the same mineral and up to six spot analysis of each standard, with reproducibility $>99.8 \%$. Oxide ZAF and Metal ZAF matrix correction methods were used. A complete list of the standards and E-line used for each element is reported in Table S1 (deposited with the Principal Editor of Mineralogical Magazine and available as Supplementary material (see below).

\section{Results}

\section{Geology of the areas}

The mineralised veins of Scar Crags occur in the 'bleached' rocks of the metasomatic aureole of Crummock Water (Figs 1, 2; Cooper et al., 1988). In the field these siltstones and mudstones are paler in colour with respect to the unaltered rocks and appear to be slightly hornfelsed, in that they are more competent and brittle, breaking along a nearly-conchoidal fracture. No increase in grain size with respect to the 'unbleached' lithologies was observed. The bedded siltstones and mudstones at Scar Crags dip predominantly towards the west at a range of angles (Fig. 2). At the Scar Crags locality this pattern is interrupted by eastwards dipping beds due to a number of medium scale folds (100-200 m wave length) with fold axes striking NE to SW. Numerous faults are present in this locality, consisting of two series of predominantly N-S and E-W trending normal and strike-slip faults (Fig. 4). Folds and faults recognised in this area can be ascribed to the regional footprints of the early- and mid-phases of the Caledonian Orogeny, with faults possibly reactivated during the Acadian phase (e.g. Stone et al., 2010). The most notable of these is a NNE-SSW trending strike-slip fault which runs parallel to the cobalt vein. The kinematics of the fault is deducible by the presence of slickensides along the eastern margin (Fig. 5), which indicates a sinistral movement. A direct association between the mineralisation and the fault can be observed as in some areas the mineralising fluid appears to have infilled the fault plane (Fig. 5). Small scale (metres to tens of metres) deformational features recorded in the area of the cobalt mineralisation could be the manifestation of the regional-scale Causey Pike Fault thrust that developed during the Grampian phase of the Caledonian Orogeny (Stone et al., 2010).
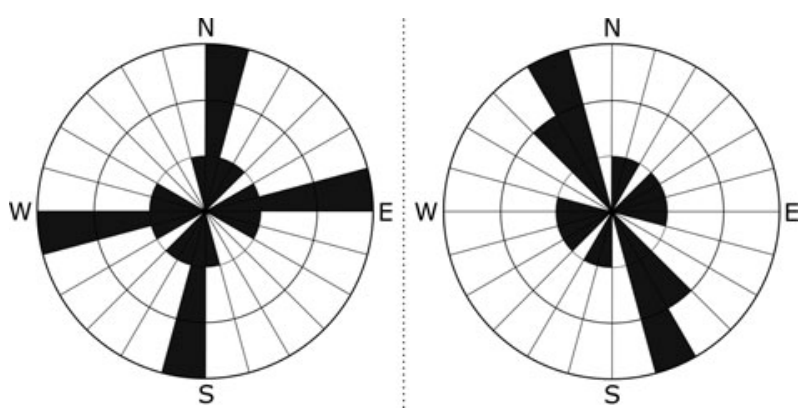

Fig. 4. (a) Rose diagram for faults trending at Scar Crags (both sets with dominant strike-slip kinematics). (b) Rose diagram for joint planes trending at Scar Crags. 


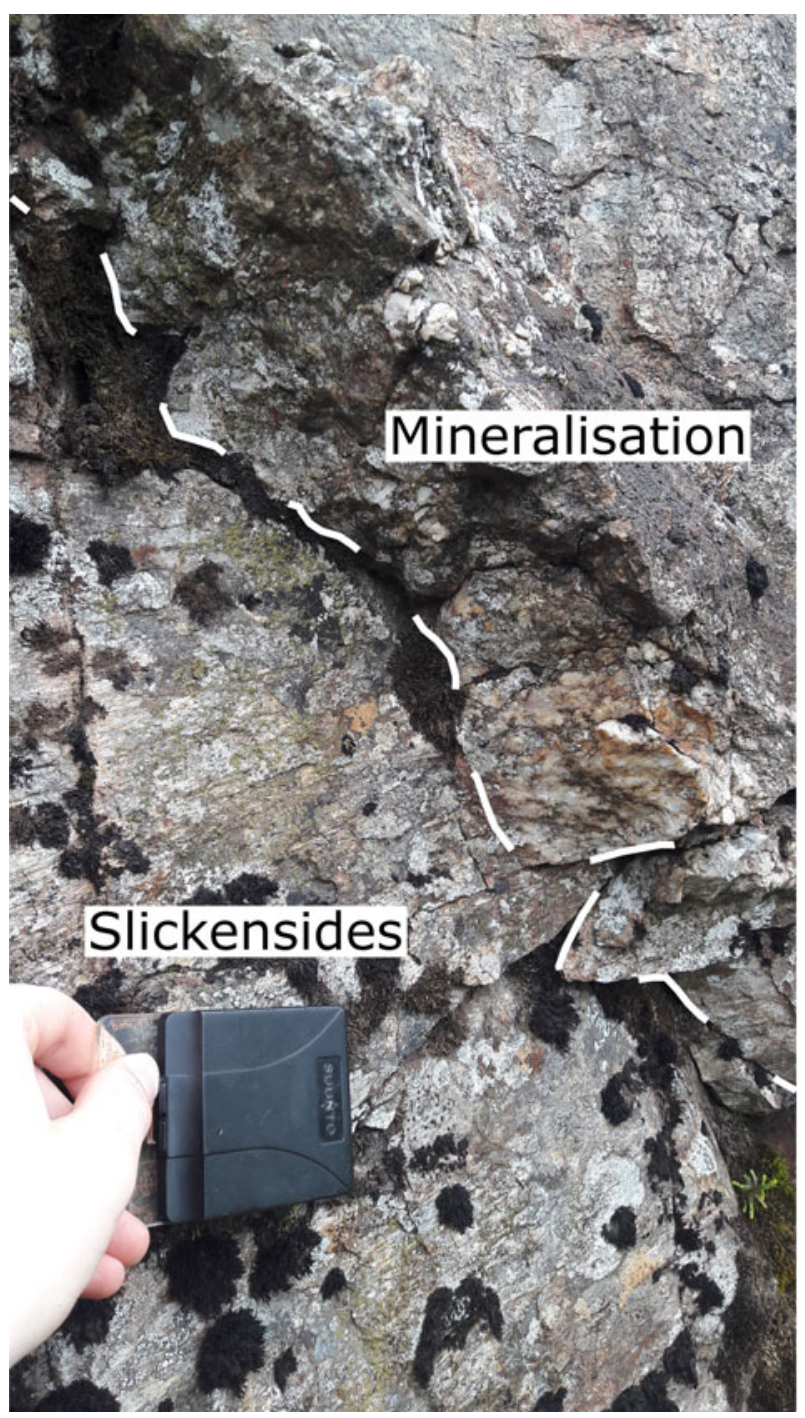

Fig. 5. Mineralisation development along the fault plane at Scar Crags (NY 205 205). The white dashed line highlights the boundary of the mineralisation.

This is confirmed by remote sensing and field observations (abrupt lithological changes and deformational structures) indicating the close proximity of the Causey Pike Fault to Scar Crags veins. A schematic representation of fault and joint planes orientation at Scar Crags is presented in Fig. 4.

The Dale Head North mineralised $\mathrm{Cu}-\mathrm{As}-\mathrm{Co}$ vein is located in close proximity $(<100 \mathrm{~m})$ to the volcanics of the Borrowdale Volcanic Group (Fig. 3). The most prominent structural feature at Dale Head North is a finely spaced, regular cleavage striking NE-SW (particularly evident in the mudstones), which continues across the boundary with the Borrowdale Volcanic Group (most visible in tuff lithologies). The development of a pervasive cleavage across rocks of the Skiddaw Group and Borrowdale Volcanic Group is ascribed to the Acadian Orogeny (Stone et al., 2010). Bedding dips homogeneously towards the S to SSE hinting to the possible localisation of the Dale Head North vein on an EW striking fault plane (curving towards the ENE east of the mineralisation - Fig. 3). The kinematics of the fault is uncertain and inferred from remote sensing combined with minor field evidence (e.g. sudden topographic changes, barely defined slickensides).

\section{Mineralogy and petrography}

\section{Scar Crags}

At Scar Crags, sulfides and sulfarsenides are found as highlyfractured grains in a gangue of quartz and chlorite, ranging in size up to $1.0 \mathrm{~mm}$ (Fig. $6 a$ ). Characteristic radiating chlorite is present throughout the vein and along the wall rock, whereas quartz forms euhedral crystals commonly associated with tourmaline. Arsenopyrite is the most abundant sulfide mineral, usually forming euhedral grains (Fig. 6b), typically associated with the $\mathrm{Co}-\mathrm{Ni}-$ Fe-bearing sulfarsenides: alloclasite (Fig. 6d,e); cobaltite; and glaucodot (Fig. 6g,h). Alloclasite is distinguishable from arsenopyrite in crossed polarised light by its 'off-blue' (occasionally purple) and green reflection anisotropy (Fig. 6d,e). Cobaltite is less common, occurring as small euhedral crystals (up to $120 \mu \mathrm{m}$, Fig. 6e,f) usually located within, or along, the boundaries between larger grains of other ore minerals. Glaucodot is significantly less common than arsenopyrite and alloclasite, and forms euhedral crystals up to 0.5 $\mathrm{mm}$ in size (Fig. 6g,h). Occasionally, glaucodot exhibits slightly darker reflection colour tones that have been confirmed as nickel-rich zones via EMPA (see section 'Mineral composition'). It is possible to distinguish alloclasite from glaucodot by the lower polishing hardness of alloclasite (resulting in a smoother surface then glaucodot) and through the grey-to-brown anisotropy of glaucodot (Ixer et al., 1979; Fig. 6g-l). Chalcopyrite (up to $1 \mathrm{~mm}$, anhedral grains with thin rims of covellite), native bismuth (maximum $0.2 \mathrm{~mm}$ inclusions or as infill of fractures in arsenopyrite, Co-sulfarsenides and quartz, occasionally with rims of bismuthinite), pyrrhotite (euhedral grains, up to $0.1 \mathrm{~mm}$, seldom with goethite overgrowths), and electrum (single grain, $50 \mu \mathrm{m}$ proximal to native bismuth) were observed. Ferroskutterudite $\left((\mathrm{Fe}, \mathrm{Co}) \mathrm{As}_{3}\right)$, tetrahedrite and wittichenite $\left(\mathrm{Cu}_{3} \mathrm{BiS}_{3}\right)$ were also identified using SEM-EDS (Table 1).

\section{Dale Head North}

The ore minerals of Dale Head North are hosted within a set of quartz-chlorite sub-veins. Two stages of quartz precipitation were observed: Earlier massive, anhedral milky quartz, followed by highly vitreous, clear and euhedral crystals. Chlorite forms radiated aggregates similar to Scar Crags. Pyrite is the most abundant ore mineral (euhedral-to-subhedral and anhedral crystals up to $1 \mathrm{~mm}$, Fig. 7a), followed by chalcopyrite (anhedral crystals, many exceeding $1 \mathrm{~mm}$, Fig. 7b). Arsenopyrite is also abundant, forming fractured, euhedral rhombs $(>1 \mathrm{~mm}$, Fig $7 \mathrm{~d})$, and as overgrowths onto sulfides (Fig. 7e), most typically pyrite. Nearly all euhedral arsenopyrite crystals show concentric and more elaborate zoning in crossed polarised light (Fig. $7 \mathrm{~d}, \mathrm{e}$ ). Pyrrhotite is the fourth major ore mineral forming anhedral crystals (up to $0.8 \mathrm{~mm}$, Fig 7c), usually as replacement of pyrite. Minor amounts of native bismuth and bismuthinite were recognised $(<0.2 \mathrm{~mm}$, Fig. 7f). Cobaltite is the only Co-bearing mineral found at Dale Head North, in the form of small, $\sim 50 \mu \mathrm{m}$, euhedral crystals located in fractures between other ore minerals. Occasionally, mediumsized $(\sim 1 \mathrm{~mm})$ crystals of sphalerite and galena were observed. A number of other minerals were identified using SEM-EDS. Specifically: apatite, allanite, cassiterite, stannite $\left(\mathrm{Cu}_{2} \mathrm{FeSnS}_{4}\right)$, rutile and zircon. Two minerals, attributed speculatively to the breakdown of allanite, were defined tentatively as rare earth element (REE) minerals: 'Y-LREE fluorocarbonates' (possibly a mineral of the bastnäsite group) and 'Y-Ti-HREE phosphate' (probably xenotime) on the basis of EDS analysis. Further details are given in Supplementary Fig. S1. 

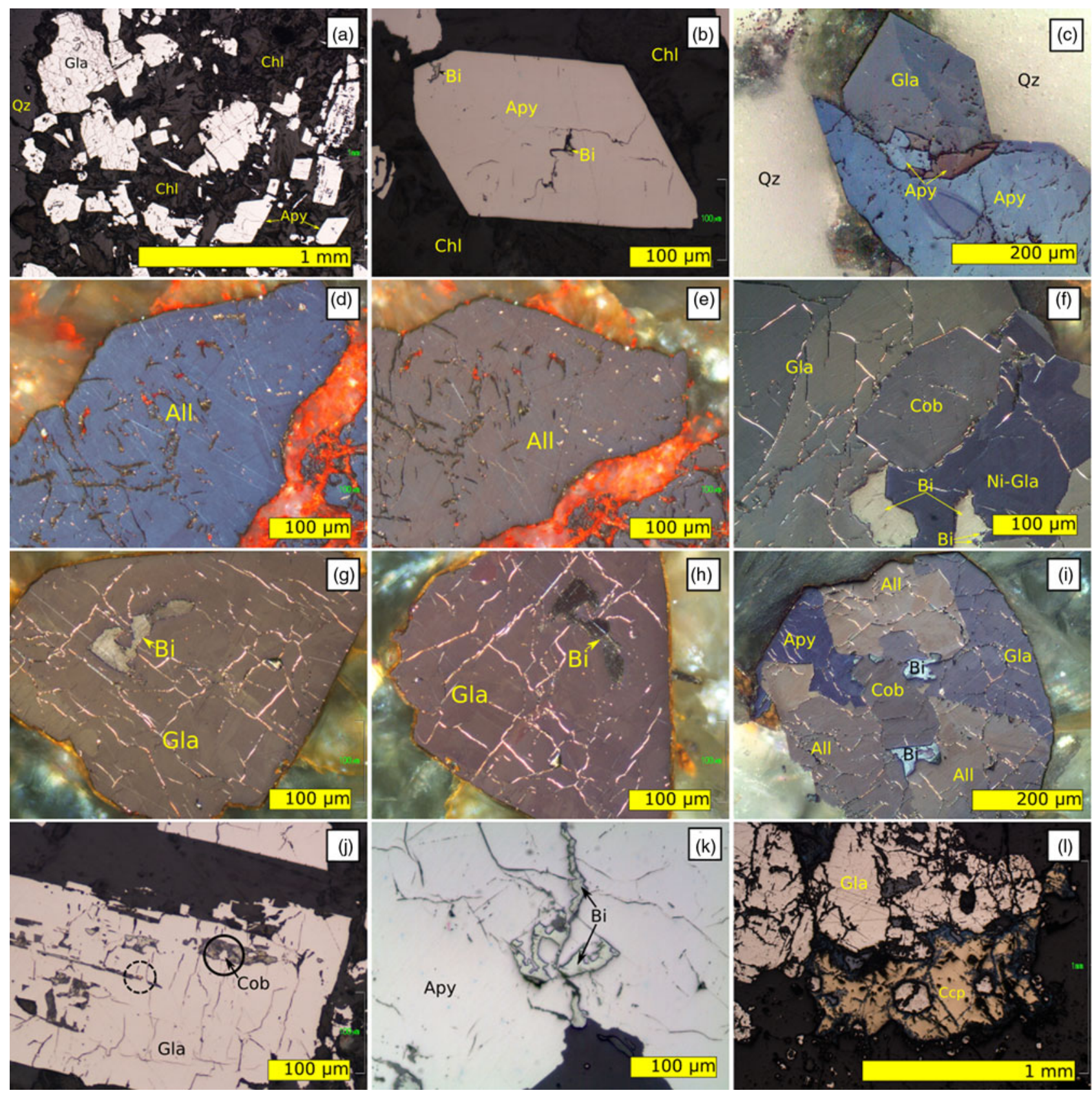

Fig. 6. (a-l) Photomicrographs of mineralisation from Scar Crags. All: Alloclasite, Bi: Native bismuth, Bis: Bismuthinite, Apy: Arsenopyrite, Chl: Chlorite, Cob: Cobaltite, Ccp: Chalcopyrite, Gla: Glaucodot, Ni-Gla: Ni-bearing glaucodot, Qz: Quartz. (a, b, j, k, l) parallel polars observation. (c-i) crossed polars observation.

\section{Mineral composition}

\section{Sulfarsenides}

The results of quantitative (wavelength dispersive spectroscopy) compositional analyses of sulfarsenides present at Scar Crags and Dale Head North (alloclasite, arsenopyrite, cobaltite and glaucodot) revealed that they are generally solid-solutions of $\mathrm{Co}$, $\mathrm{Fe}$ and $\mathrm{Ni}$ end-members, with an exception being that arsenopyrite does not show measurable amounts of Ni (Fig. 8; Table 2). Due to the extensive compositional zoning observed in many sulfarsenide grains, as seen via X-ray elemental mapping (e.g. Figs 9, 10), it is possible that the range of composition for each of the minerals extends beyond those obtained via quantitative spot analyses operated with the EMPA. Specific mineral grains that show very similar composition and near-identical grey tone in BSE imaging (alloclasite, cobaltite and glaucodot) were targeted after optical verification of their mineral species (see section 'Mineralogy and petrography'). Alloclasite and glaucodot (only present at Scar Crags) hosted $<10.0$ and $>11.0$ wt.\% $\mathrm{Fe}$, respectively. Glaucodot contains maximum $1.4 \mathrm{wt} . \% \mathrm{Ni}$, but up to $14.1 \mathrm{wt} . \%$, if a particular grain, SA-2, with extensive compositional zoning were to be defined as glaucodot. Arsenopyrite showed markedly different characteristics at Scar Crags (Co is always present and up to $4.2 \mathrm{wt} . \%$ with no apparent zoning) to Dale Head North (insignificant Co content, complex As-Sb zoning, with $\mathrm{Sb}$ content between 0.0 and 3.3 wt.\%). Cobaltite is 
Table 1. Mineralogy (in alphabetical order).

\begin{tabular}{|c|c|c|}
\hline Mineral & Scar Crags & Dale Head North \\
\hline Allanite & & $+{ }^{*}$ \\
\hline Alloclasite & ++++ & \\
\hline Apatite & & ++++ * \\
\hline Arsenopyrite & ++++ & ++++ \\
\hline Bismuth & +++ & +++ \\
\hline Bismuthinite & ++ & ++ \\
\hline Cassiterite & & + \\
\hline Chalcopyrite & +++ * & ++++ \\
\hline Chlorite & ++++ & ++++ \\
\hline Cobaltite & +++ & +++ \\
\hline Covellite & ++ & \\
\hline Electrum & ++ * & \\
\hline Ferroskutterudite & + & \\
\hline Galena & & \\
\hline Glaucodot & +++ & \\
\hline Marcasite & & ++++ \\
\hline Pyrite & +++ & ++++ \\
\hline Pyrrhotite & +++ * & +++ \\
\hline Quartz & ++++ & ++++ \\
\hline Rutile & & + \\
\hline Sphalerite & & ++ \\
\hline Stannite & & $+{ }^{*}$ \\
\hline Tetrahedrite & $+^{\star}$ & \\
\hline Tourmaline & ++++ & \\
\hline Wittichenite & $+^{\star}$ & \\
\hline Y-HREE-phosphate & & $+{ }^{*}$ \\
\hline Y-LREE-fluorocarbonate & & $+{ }^{*}$ \\
\hline Zircon & & $+{ }^{*}$ \\
\hline
\end{tabular}

Abundance of minerals: ++++ common; +++ minor; ++ rare; + very rare, identified with SEM-EDS.

${ }^{\star}$ First record of the mineral at the location.

Ni-free at Scar Crags (except for a particular grain, SA-1, with complex zoning and up to $14.2 \mathrm{wt} . \% \mathrm{Ni}$, if accepted as cobaltite - see further in this section), but it contains up to $3.0 \mathrm{wt} . \% \mathrm{Ni}$ at Dale Head North. A special case is represented by a relatively large $(\sim 2 \mathrm{~mm} \times 2 \mathrm{~mm})$ crystal of glaucodot (labelled SA-2), which seems to have engulfed a smaller cobaltite grain $(0.15 \mathrm{~mm}$ $\times 0.10 \mathrm{~mm}$, labelled SA-1) in a sample from Scar Crags, both of which show extensive and complex zonation (Figs 9, 10). In BSE imaging mode various grey tones are evident and after collection of high-resolution X-ray elemental maps for As, Co, Fe, Ni and $\mathrm{S}$, it was possible to target specific areas of each of the two grains and measure maximum and minimum contents of Co, $\mathrm{Fe}$ and $\mathrm{Ni}$. The Ni content of the small cobaltite crystal ranges from 0.3 to $14.2 \mathrm{wt}$.\%, whereas in the large glaucodot grain it varies between 6.0 and $14.1 \mathrm{wt}$.\%. The high Ni-content in cobaltite is ascribed to solid solution with the Ni end-member gersdorffite (NiAsS), whereas for glaucodot, it is only possible to define the crystal as Ni-glaucodot. All compositions are reported in Table 2.

\section{Sulfides}

Chalcopyrite, covellite, galena and pyrrhotite showed nearly stoichiometric composition and no zonation where present at Scar Crags and Dale Head North. Bismuthinite containing up to $3.8 \mathrm{wt} . \% \mathrm{Sb}$ was found at Scar Crags. Sphalerite and stannite, found at Dale Head North only, contained up to $8.2 \mathrm{wt} \%$ $\mathrm{Fe}$ and 1.6 wt.\% $\mathrm{Zn}$, respectively. The most notable feature of the sulfide minerals is the presence of As-bearing patchy zones inside pyrite at Dale Head North (Supplementary material, Fig. S2). Electron microprobe spot analysis revealed up to 1.6 wt.\% As. The darker grey tone of the As-bearing zones in BSE imaging (Fig. S2) suggests the presence of elemental arsenic rather than arsenopyrite inclusions. This could be ascribed to the breakdown of pyrite at low temperature associated with leaching of arsenic from the sulfarsenides which then precipitated in pyrite micropores (e.g. Le Pape et al., 2016). Compositional analyses of sulfides are reported in Table 3.

\section{Other minerals}

Non-sulfarsenide and non-sulfide ore minerals, as well as ferroskutterudite and wittichenite were only analysed with EDS, thus no full quantitative interpretation of their chemistry is possible. A summary of the mineral species identified, and their composition is reported in the Supplementary material, Table S2.

The common presence of native bismuth and bismuth minerals such as bismuthinite, $(\mathrm{Pb})$-Bi-telluride, and Bi-selenide (seldom associated with electrum) is worthy of mention and more details regarding the composition of these minerals are also reported in Table S2)

\section{Discussion \\ Structures and lithologies}

The only detailed attempt to correlate deformational events with mineralisation development is reported by Cooper et al. (1988). These authors attribute N-S oriented vein emplacement to joint plane infill and considered that E-W trending folds are a key element influencing mineralising fluid migration. In contrast, this investigation revealed numerous NE-SW to NNE-SSW trending folds in the area proximal to the mineralisation of Scar Crags and Dale Head North, and showed that the Co-rich veins of Scar Crags are emplaced on a fault plane (Figs 2, 5; section 'Geology of the areas', in 'Results').

\section{Paragenetic sequences and mineralogy}

At Scar Crags chalcopyrite, electrum, pyrrhotite, tetrahedrite and wittichenite have not been reported previously, however apatite, marcasite, molybdenite, muscovite and rutile were not observed in the samples investigated (cfr. Ixer et al., 1979). Samples from Dale Head North contained allanite, apatite, stannite and zircon, also not reported previously, but gold, muscovite and tennantite (cfr. Stanley and Vaughan, 1980) were not observed. The use of textural characteristics to define a paragenetic sequence is discussed below.

\section{Scar Crags}

The mineralisation at Scar Crags started with deposition of quartz and minor amounts of tourmaline (intergrown with quartz), followed closely by radial chlorite precipitation, that seldom occupies the intergranular space of quartz. These minerals might represent a very early short-lived precipitation from sulfur-absent or sulfurpoor fluids, though limited evidence for chlorite-sulfarsenide intergrowths was found. The main stage of ore mineral precipitation (stage 1, Fig. 11) followed, with formation of all or most of the sulfarsenides suite, as evidenced by ore mineral grain boundaries cutting across chlorite needles and laths (Fig. 6a). During stage 1, euhedral, rhombic Co-rich arsenopyrite formed first, as it does not cut across any other ore mineral grain boundary. A second phase of arsenopyrite is evidenced from the presence of subhedral grains displaying marked $\mathrm{Fe}-\mathrm{Co}-\mathrm{Ni}$ zoning (Fig. 6c, d). Precipitation of Ni-bearing glaucodot (e.g. SA-2, Fig. 10) appears to be synchronous with the second phase of arsenopyrite, 

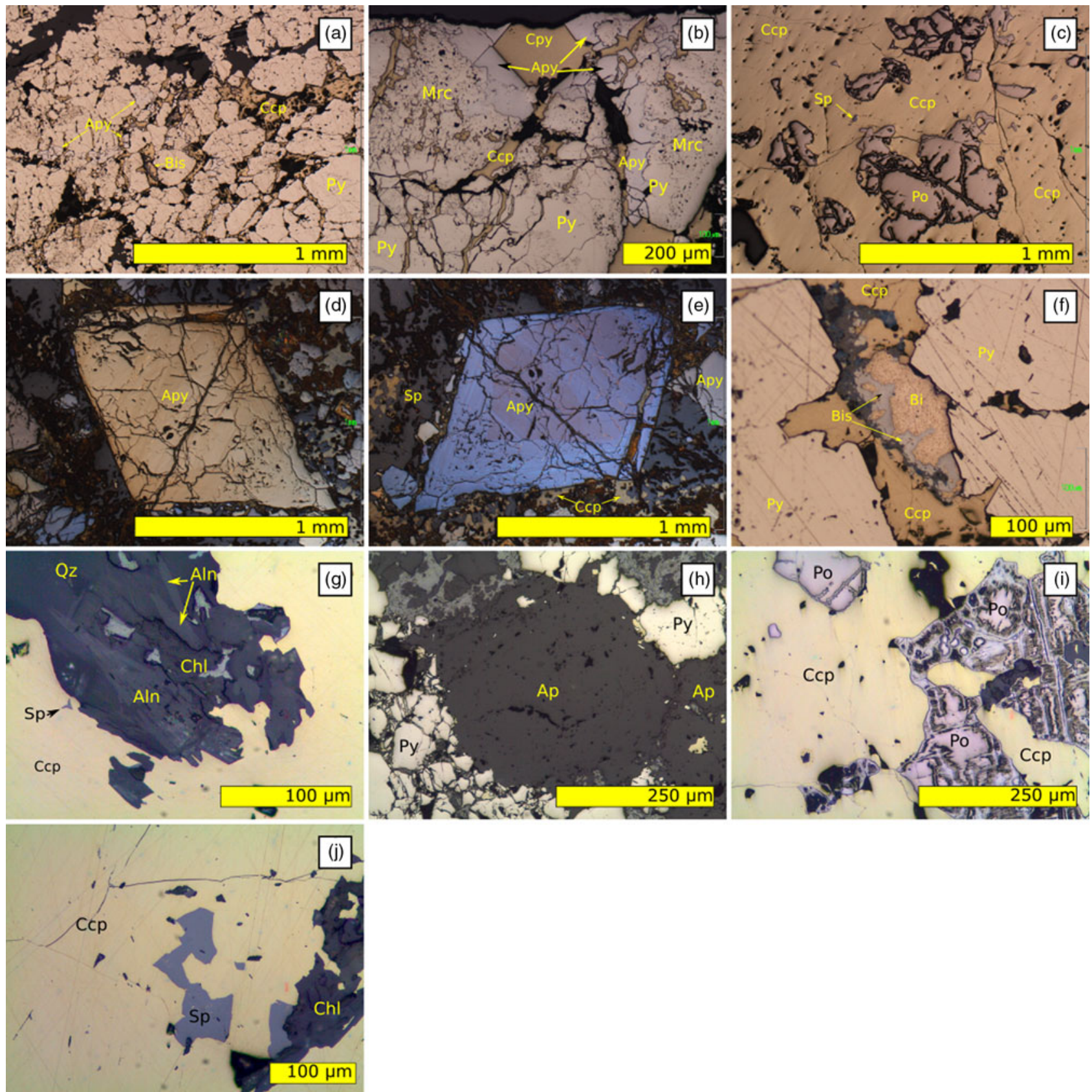

Fig. 7. (a-j) Photomicrographs of mineralisation from Dale Head North. Aln: Allanite, Ap: Apatite, Apy: Arsenopyrite, Bi: Native bismuth, Bis: Bismuthinite, Chl: Chlorite, Ccp: Chalcopyrite, Mrc: Marcasite, Po: Pyrrothite, Py: Pyrite, Qz: Quartz, Sp: Sphalerite. (d, e) Crossed polars observation, all other photos taken in parallel polars mode.

through comparison with their relationships with other minerals (subhedral arsenopyrite and Ni-glaucodot are never actually in contact, Fig. 6i). Ni-bearing cobaltite might have precipitated after the first phase of arsenopyrite, as it is in one instance present as an inclusion within the zoned glaucodot (Fig. 6f). Un-zoned glaucodot was formed after the second phase of arsenopyrite as it overgrows it (Fig. 6c). Penecontemporaneous precipitation of alloclasite with glaucodot is inferred by occasional replacement of earlier glaucodot, while typically the two share straight grain boundaries (Fig. 6i). Alloclasite also shows intergrowths with the second-phase subhedral arsenopyrite (Fig. 6i). Ni-free cobaltite (labelled just 'cobaltite' in Fig. 11) precipitation followed alloclasite and all of the aforementioned sulfarsenides. This is evidenced by cobaltite crystals located along other sulfarsenide grain boundaries or within vugs formed between those crystals (Fig. 6j). Cobaltite also forms euhedral crystals $(<100 \mu \mathrm{m})$ along fractures within arsenopyrite. The second stage (stage 2 ) of the paragenetic sequence involves precipitation of the non-sulfarsenide minerals. It is difficult to place tetrahedrite and wittichenite in sequence (both were identified via electron spectroscopy and show no clear association with any of the sulfarsenides), but their formation might be an indicator of a change of the composition of the mineralising fluids (from $\mathrm{As}-\mathrm{Co}-\mathrm{Ni}$ dominated to $\mathrm{Ag}-\mathrm{Au}-$ $\mathrm{Bi}-\mathrm{Cu}-\mathrm{Sb}-\mathrm{Zn}$ bearing). Tetrahedrite appears to be replaced partly 


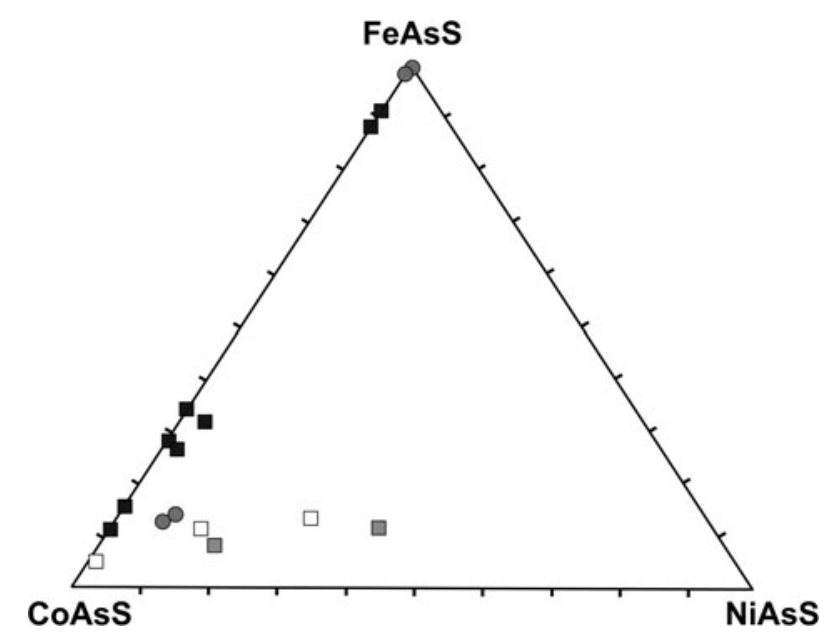

Fig. 8. Composition of sulfarsenides. Squares are sulfarsenides from Scar Crags, circles are from Dale Head North. Empty squares are analyses of grain SA-1, and greyfilled squares are analyses from grain SA-2 (see 'Results' and Fig. 8).

by native bismuth and cross-cut by bismuthinite. Wittichenite is overgrown, and replaced partially by bismuthinite. Native bismuth forms predominantly subhedral and anhedral crystals infilling fractures in the sulfarsenides (Fig. 6k) and it is usually replaced partially or fully by bismuthinite. Electrum is observed in close association with bismuthinite forming an adjacent small anhedral crystal (Fig. 6j). Few crystals of pyrite and pyrrhotite precipitated towards the end of the mineralisation sequence, with the former appearing typically as overgrowths onto sulfarsenides. Pyrrhotite precipitation took place before pyrite as observed by replacement textures. During the last phases of mineral precipitation, chalcopyrite was formed (overgrowths onto the earlier sulfarsenides and sulfides), followed by covellite (Fig. 6l). The second stage of mineral precipitation might be attributed to a change in the composition of the fluids, similar to a transition from high-sulfidation (sulfarsenides) to medium- and then lowsulfidation (presence of $\mathrm{Ag}, \mathrm{Au}, \mathrm{Bi}, \mathrm{Sb}$ and transition from pyrrhotite to pyrite; e.g. Ahmed et al., 2009).

\section{Dale Head North}

Four stages of mineralisation were recognised at Dale Head North. Stage 1: An initial phase of sulfur-free mineral precipitation (Fig. 12) is evident after petrographic examination of samples from Dale Head North. Quartz was the first phase to precipitate, displaying two phases of growth (see section 'Dale Head North' in 'Mineralogy and petrography' of 'Results'), and it is intergrown with allanite (Fig. 7g). Apatite does not show direct relationships with quartz or allanite, though it is overgrown and to lesser extent replaced by sulfides and sulfarsenides, indicating early precipitation (Fig. 7h). Chlorite is the last mineral to form during stage 1 , indicated by the presence of chlorite needles cutting across allanite and chlorite replaced apatite (Fig. 7g). Stage 2: The precipitation of chlorite continued from stage 1 until formation of the first sulfur-bearing mineral, pyrite, with which it shares occasional straight boundaries (yet chlorite grain boundaries are cut across by all other sulfides and sulfarsenides). Pyrite in the form of euhedral crystals is the first formed and the most abundant metallic mineral at Dale Head North. It marks the start of stage 2, although a second generation of pyrite crystal growth is recorded in a later stage (stage 4 ; see below and Fig. 12). Stage 3: The third phase of mineral precipitation began with cassiterite found as subhedral grains formed within fractures of stage 2 pyrite (though rare). All sulfarsenides and bismuth-bearing minerals were precipitated during stage 3. Arsenopyrite formed euhedral rhombs overgrowing early-stage pyrite (Fig. 7). Cobaltite is difficult to position within the sequence due to the scarcity of grains.

Table 2. Representative compositions of sulfarsenide minerals from EPMA.

\begin{tabular}{|c|c|c|c|c|c|c|c|c|c|c|c|}
\hline Location & Mineral species & Grain & $\mathrm{S}$ & As & $\mathrm{Fe}$ & $\mathrm{Sb}$ & Co & $\mathrm{Ni}$ & Total & & Fig. / analysis \# \\
\hline \multirow[t]{14}{*}{ Scar Crags } & Alloclasite & & 19.85 & 45.04 & 9.94 & bdl & 25.73 & 0.38 & 100.94 & & \\
\hline & Alloclasite & & 19.99 & 44.77 & 10.00 & bdl & 25.62 & 0.20 & 100.58 & & \\
\hline & Cobaltiferous arsenopyrite & & 20.28 & 44.89 & 30.29 & 0.29 & 4.16 & bdl & 99.91 & & \\
\hline & Cobaltiferous arsenopyrite & & 20.16 & 45.55 & 31.33 & 0.25 & 3.20 & 0.02 & 100.52 & & \\
\hline & Cobaltite & & 20.58 & 44.53 & 5.52 & bdl & 29.58 & 0.01 & 100.22 & & \\
\hline & Glaucodot & & 19.73 & 44.87 & 12.16 & bdl & 23.46 & bdl & 100.22 & & \\
\hline & Glaucodot & & 19.64 & 45.34 & 12.31 & bdl & 23.49 & bdl & 100.78 & & \\
\hline & Glaucodot & & 20.42 & 45.58 & 11.28 & bdl & 23.17 & 1.41 & 101.86 & * & \\
\hline & Co-Fe-Ni sulfarsenide & SA-1 & 20.33 & 45.24 & 2.00 & bdl & 34.33 & 0.25 & 102.15 & & Fig. 10; “1” \\
\hline & Co-Fe-Ni sulfarsenide & SA-1 & 20.14 & 45.55 & 4.07 & bdl & 27.30 & 5.02 & 102.08 & * & Fig. 10; “2” \\
\hline & Co-Fe-Ni sulfarsenide & SA-1 & 19.47 & 46.60 & 4.00 & bdl & 17.66 & 14.23 & 101.96 & * & Fig. 10; “3” \\
\hline & Co-Fe-Ni sulfarsenide & SA-1 & 19.75 & 46.60 & 4.88 & bdl & 20.95 & 10.23 & 102.41 & * & Fig. 10; "4" \\
\hline & Co-Fe-Ni sulfarsenide & SA-2 & 19.87 & 45.82 & 3.04 & bdl & 27.09 & 6.07 & 101.89 & * & Fig. 10; “1” \\
\hline & Co-Fe-Ni sulfarsenide & SA-2 & 19.45 & 46.22 & 4.02 & bdl & 17.49 & 14.14 & 101.32 & * & Fig. 10; "2" \\
\hline \multirow[t]{10}{*}{ Dale Head North } & Arsenopyrite & & 21.75 & 44.03 & 34.83 & 0.04 & 0.09 & bdl & 100.74 & & \\
\hline & Arsenopyrite & & 23.13 & 41.37 & 34.61 & 0.18 & 0.26 & bdl & 99.54 & & \\
\hline & Arsenopyrite & & 24.66 & 38.71 & 35.83 & 1.11 & 0.07 & 0.02 & 100.40 & & \\
\hline & Arsenopyrite & & 21.59 & 40.94 & 34.21 & 3.34 & 0.06 & bdl & 100.14 & & Fig. 9; “1” \\
\hline & Arsenopyrite & & 23.29 & 41.28 & 35.31 & 0.22 & 0.09 & bdl & 100.19 & & Fig. 9; "2" \\
\hline & Arsenopyrite & & 22.40 & 41.07 & 34.77 & 2.36 & 0.06 & 0.01 & 100.68 & & Fig. 9; “3” \\
\hline & Arsenopyrite & & 22.16 & 42.63 & 34.55 & 1.19 & 0.06 & 0.01 & 100.60 & & \\
\hline & Arsenopyrite & & 21.60 & 43.89 & 34.46 & 0.10 & 0.05 & 0.02 & 100.11 & & \\
\hline & Cobaltite & & 21.07 & 44.39 & 4.89 & 0.16 & 28.26 & 3.02 & 98.77 & * & \\
\hline & Cobaltite & & 20.75 & 44.71 & 4.52 & 0.12 & 28.90 & 2.76 & 99.00 & * & \\
\hline
\end{tabular}

* Low or high totals attributed to issues with standardisation of $\mathrm{Ni}$, though repeated measurements of the standard returned reproducibility to $>99.3 \%$ bdl $=$ below detection 


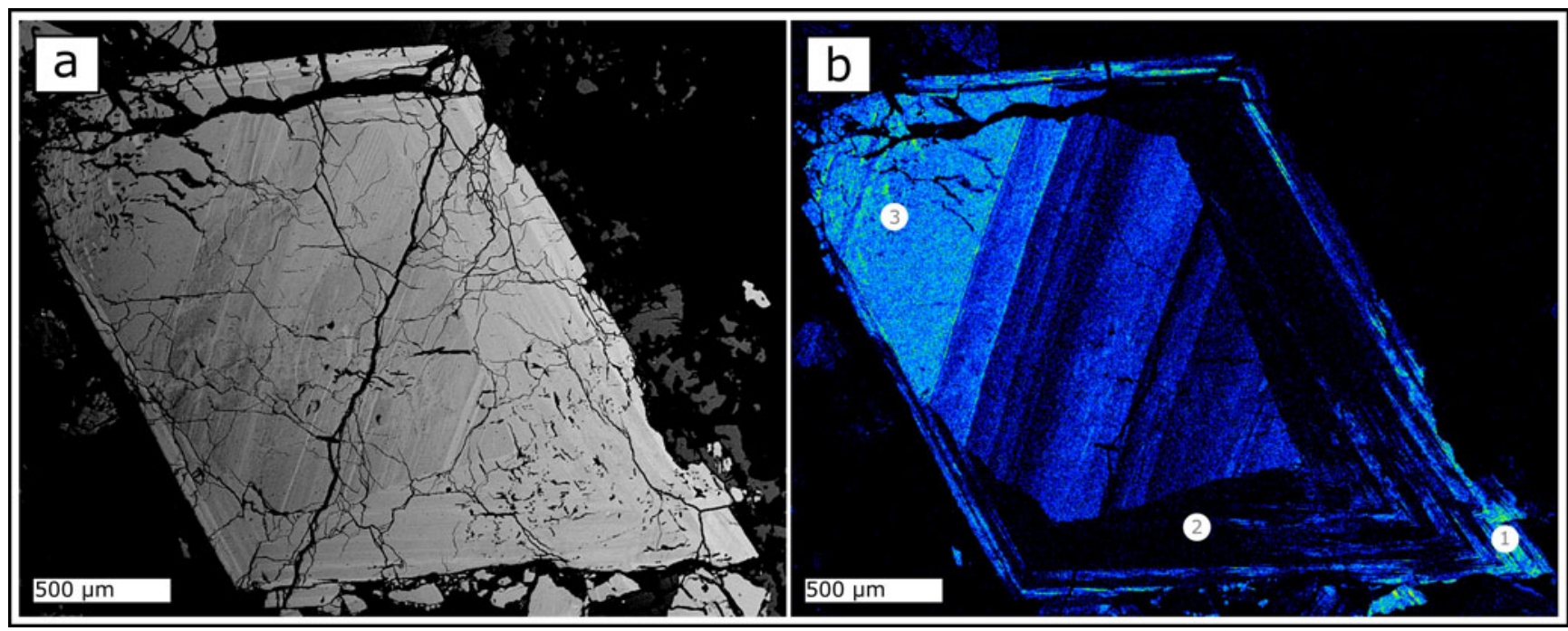

Fig. 9. (a) Back-scattered electron image of zoned arsenopyrite crystal from Dale Head North. (b) X-ray antimony elemental map of the same crystal. 1, 2, and 3 indicate spot EMPA analyses, reported in Table 2 as "1", "2", and "3", where arsenopyrite zones contain 3.3, 0.2, and 2.4 wt.\% Sb, respectively.
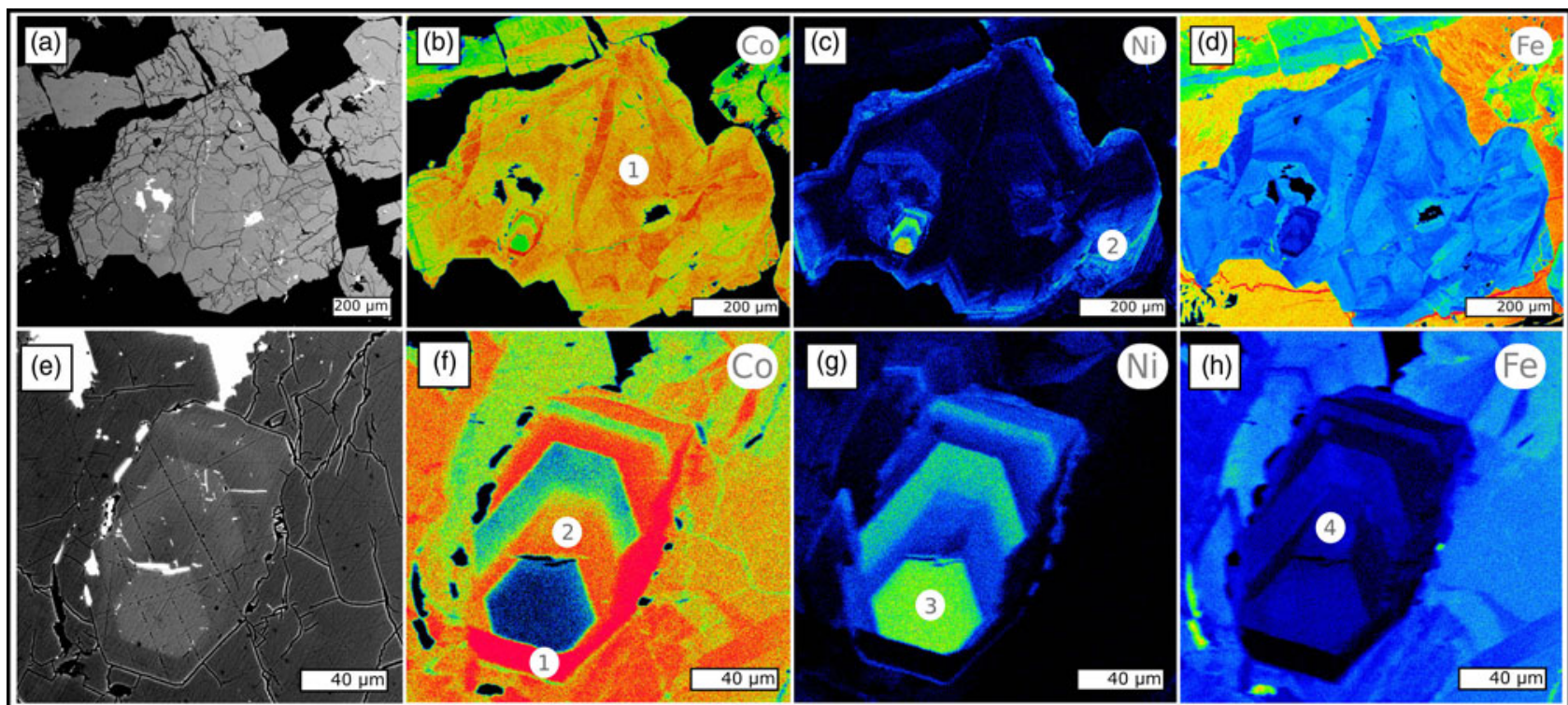

Fig. 10. (a) Back-scattered electron image of zoned glaucodot (SA-2) and cobaltite (SA-1) crystals from Scar Crags. (b-c) X-ray cobalt, nickel and iron elementdistribution maps of the same crystals as in (a). (e) Back-scattered electron image of zoned cobaltite (SA-1) crystal from Scar Crags. ( $f$-h) X-ray cobalt, iron, and nickel element-distribution maps of the same crystal as in (e). 1, 2 in panels (b-d) indicate spot EMPA, reported in Table 2 as " 1 ", "2" (for grain SA-2). 1, 2,3 and 4 in panels ( $\mathrm{f}-\mathrm{h}$ ) indicate spot EMPA, reported in Table 2 as " 1 ", " 2 ", " 3 " and " 4 " (for grain SA-1).

It can be found as overgrowths on both pyrite and arsenopyrite and along fractures within the latter. Native bismuth is not present within sulfarsenides (contrarily to Scar Crags), but exclusively in fractures and overgrowths of euhedral pyrite (Fig. 7f). Native bismuth is typically replaced partially by bismuthinite (Fig. 7f). Crystallisation of pyrrhotite might have occurred during stage 3 but it forms no mutual grain boundaries other than with chalcopyrite, thus, it cannot be placed coherently in the paragenetic sequence. Stanley and Vaughan (1980) noted that pyrrhotite appears to surround bismuth-bismuthinite and tends to replace pyrite throughout the mineralisation. No evidence of this was observed in the current investigation. Stage 4: The sulfide minerals were formed during the fourth stage of precipitation. Chalcopyrite, galena, sphalerite and stannite are probably co-precipitated as they all form infills of fractures in minerals from stage 2 and 3 (Fig. 7a, b, f). A second generation of euhedral pyrite crystals cutting across the grain boundaries of arsenopyrite (Fig. 7b) was also formed during this stage. Occasionally, these pyrite grains present patchy zones with $>1$ wt.\% As (see section 'Mineral composition') (Fig. S2). Chalcopyrite is by far the most abundant mineral of stage 4 , it occupies the majority of fractures between sulfarsenides and the first generation of pyrite, and it has substantially replaced pyrrhotite (pyrrhotite is only present as inclusions within chalcopyrite, Fig. 7c, i). Marcasite (always presenting a 'sponge-like' texture) forms replacements of pyrite throughout most of the samples (Fig. 7b). Stanley and Vaughan (1980) indicated that marcasite also replaces chalcopyrite and pyrrhotite, and assuming that this is the case, it has been placed 
Table 3. Representative compositions of sulfide minerals from EPMA.

\begin{tabular}{|c|c|c|c|c|c|c|c|c|c|c|c|}
\hline Locality & Mineral species & $\mathrm{S}$ & As & $\mathrm{Zn}$ & $\mathrm{Fe}$ & $\mathrm{Sb}$ & Se & Sn & $\mathrm{Cu}$ & $\mathrm{Bi}$ & Total \\
\hline \multirow[t]{11}{*}{ Scar Crags } & Bismuthinite $^{\star}$ & 18.61 & 0.04 & 0.03 & 0.05 & 3.76 & 0.21 & bdlf & 0.27 & 74.24 & 97.21 \\
\hline & Bismuthinite $^{\star}$ & 18.65 & 0.08 & 0.01 & 0.08 & 3.69 & 0.22 & bdl & 0.23 & 74.33 & 97.28 \\
\hline & Bismuthinite* & 19.08 & 0.10 & 0.04 & 0.04 & 3.30 & 0.22 & bdl & 0.47 & 73.12 & 96.35 \\
\hline & Bismuthinite* & 18.99 & 0.11 & bdl & 0.12 & 3.27 & 0.22 & bdl & 0.31 & 74.16 & 97.16 \\
\hline & Bismuthinite* & 18.10 & 0.05 & bdl & 0.01 & 0.65 & 0.39 & bdl & 0.32 & 77.18 & 96.70 \\
\hline & Chalcopyrite & 34.78 & 0.01 & bdl & 29.82 & bdl & 0.04 & 0.07 & 34.34 & bdl & 99.06 \\
\hline & Covellite & 32.61 & bdl & bdl & 0.38 & 0.42 & bdl & bdl & 65.85 & 0.06 & 99.31 \\
\hline & Pyrite & 53.33 & 0.02 & 0.01 & 46.09 & bdl & 0.01 & bdl & 0.02 & bdl & 99.48 \\
\hline & Pyrite & 52.46 & bdl & bdl & 46.41 & bdl & 0.01 & bdl & 0.01 & bdl & 98.89 \\
\hline & Pyrite & 53.02 & bdl & bdl & 45.89 & bdl & 0.03 & bdl & bdl & bdl & 98.94 \\
\hline & Pyrrhotite & 39.48 & bdl & bdl & 58.84 & 0.01 & bdl & bdl & 0.11 & bdl & 98.44 \\
\hline \multirow[t]{17}{*}{ Dale Head North } & Bismuthinite & 18.42 & 0.09 & bdl & 0.62 & 0.12 & 0.08 & bdl & 0.56 & 79.58 & 99.47 \\
\hline & Chalcopyrite & 34.87 & 0.01 & 0.01 & 30.14 & bdl & 0.01 & 0.03 & 33.74 & bdl & 98.81 \\
\hline & Chalcopyrite & 35.21 & bdl & 0.71 & 29.70 & bdl & 0.05 & 0.08 & 33.70 & bdl & 99.45 \\
\hline & Chalcopyrite & 34.86 & 0.01 & bdl & 29.63 & bdl & bdl & 0.03 & 33.70 & bdl & 98.23 \\
\hline & Chalcopyrite & 34.39 & bdl & 0.04 & 29.88 & bdl & 0.03 & 0.12 & 34.06 & bdl & 98.52 \\
\hline & Chalcopyrite & 34.84 & bdl & bdl & 29.86 & bdl & 0.03 & 0.09 & 34.02 & bdl & 98.84 \\
\hline & Chalcopyrite & 34.93 & bdl & bdl & 30.00 & bdl & 0.02 & 0.04 & 34.03 & bdl & 99.02 \\
\hline & Chalcopyrite & 35.30 & bdl & 0.04 & 30.07 & bdl & bdl & 0.11 & 34.04 & bdl & 99.56 \\
\hline & Pyrite & 53.82 & bdl & 0.01 & 46.07 & bdl & bdl & bdl & 0.01 & bdl & 99.91 \\
\hline & Pyrite & 52.15 & 1.32 & bdl & 45.14 & 0.04 & bdl & bdl & 0.03 & bdl & 98.69 \\
\hline & Pyrite & 53.17 & 0.01 & bdl & 45.22 & bdl & bdl & bdl & 0.66 & bdl & 99.07 \\
\hline & Pyrite & 52.20 & 1.59 & 0.01 & 45.71 & bdl & bdl & bdl & bdl & bdl & 99.51 \\
\hline & Pyrite & 53.14 & 0.01 & bdl & 45.58 & bdl & bdl & 0.01 & 0.22 & bdl & 98.95 \\
\hline & Pyrrhotite & 39.55 & 0.02 & bdl & 59.30 & bdl & bdl & 0.01 & bdl & bdl & 98.89 \\
\hline & Pyrrhotite & 39.63 & 0.04 & bdl & 59.33 & bdl & bdl & 0.05 & bdl & bdl & 99.05 \\
\hline & Sphalerite & 33.03 & 0.03 & 58.51 & 8.23 & bdl & 0.01 & bdl & 0.22 & bdl & 100.03 \\
\hline & Stannite & 29.52 & 0.01 & 1.55 & 12.68 & bdl & 0.05 & 27.38 & 29.21 & bdl & 100.40 \\
\hline
\end{tabular}

* Low totals for bismuthinite in the samples from Scar Crags attributed to oxidation of the mineral as per EDS analysis flagging > 1 wt.\% oxygen. bdl = below detection limit

at the end of the paragenetic sequence. As in Scar Crags, there appears to be a transition from low sulfur- (stage 3) to high sulfur-bearing (stage 4 ) type mineralising fluids.

\section{Comparison between mineralisation and with previous findings}

In both localities, growth of the various sulfarsenides overlapped and precipitated after silicates and oxides, followed by copper, iron (or copper, iron, lead, tin and zinc) sulfides and possibly sulfosalts. However, at Dale Head North, the first minerals formed are oxides, phosphates and silicates only, followed by chlorite and possibly pyrite, whereas at Scar Crags the sulfarsenides precipitated very early and are seldom intergrown with chlorite. This might indicate a first stage of oxidised and/or sulfur-poor fluids pulse at Dale Head North, which is not (or barely) recorded at Scar Crags.

In comparison with previous studies of the ore minerals forming the Scar Crags and Dale Head North veins this investigation has identified the presence of Ni-bearing sulfarsenides at Scar Crags, in notable contrast with Ixer et al. (1979), who indicated the absence of nickel minerals is a key factor to differentiate Dale Head North from Scar Crags cobalt-arsenic mineralisation. In addition, this has implications for the maximum temperature of formation of sulfarsenides at Scar Crags, because Ni expands their stability field to and above $350^{\circ} \mathrm{C}$ (Petruk et al., 1971). Another fundamental observation is the presence of significant amounts of elements other than Fe and As in arsenopyrite, specifically Co, Ni and/or Sb. Kretschmar and Scott (1976) indicated that the arsenopyrite geothermometer is not reliable if the mineral contains impurities in excess of $1 \mathrm{wt} . \%$, as it is the case for the majority of arsenopyrite grains at Scar Crags and Dale Head North (Tables 2,3). Geothermometric inferences used by Ixer et al. (1979) to define the activity of sulfur, $a_{\mathrm{S}_{2}}$, at Scar Crags was based on arsenopyrite geothermometry, and should be re-evaluated. The presence of compositional zoning in all of the sulfarsenides (Figs 9, 10) discards the hypothesis that optical zonation, evident in crossed polar observation, are related to deformation and/or exsolution processes (Ixer et al., 1979). Sudden changes of $\mathrm{Co}, \mathrm{Fe}, \mathrm{Ni}$ and/or Sb content at the scale of tens of micrometres in arsenopyrite grains (and in most of the other sulfarsenides, except for the absence of antimony) could be attributed to: (1) vigorous compositional mixing in the mineralising fluids at the scale of the individual vein/pockets; or (2) sudden changes of physical conditions, e.g. pH, Eh, T, P or $a_{\mathrm{S}_{2}}$ (Kretschmar and Scott 1976; Lowell and Gasparrini 1982; Vesselinov et al., 1995; Shore and Fowler, 1996). If we extend our observation to the whole paragenesis, a change in temperature and/or an increase of $a_{\mathrm{S}_{2}}$ is envisaged to foster precipitation of sulfides after the Co-Ni-sulfarsenide stage in both localities, and the late-stage precipitation of native bismuth suggests a subsequent lowering of $a_{S_{2}}$. At Dale Head North the appearance of marcasite after stage 4 , suggests a decrease of the $\mathrm{pH}$ of the fluid. A different, more complex scenario could be envisaged if two or more competing sources of fluids are capable of entering the same space synchronously (see section 'Genesis of mineralisation and fluids pathways' in 'Discussion').

A fluid-inclusion study was not carried out, and the arsenopyrite geothermometer could not be used to refine mineral precipitation conditions. Nevertheless, the paragenetic sequence reconstruction coupled with the attempted reconstruction of $a_{\mathrm{S}_{2}}$ 


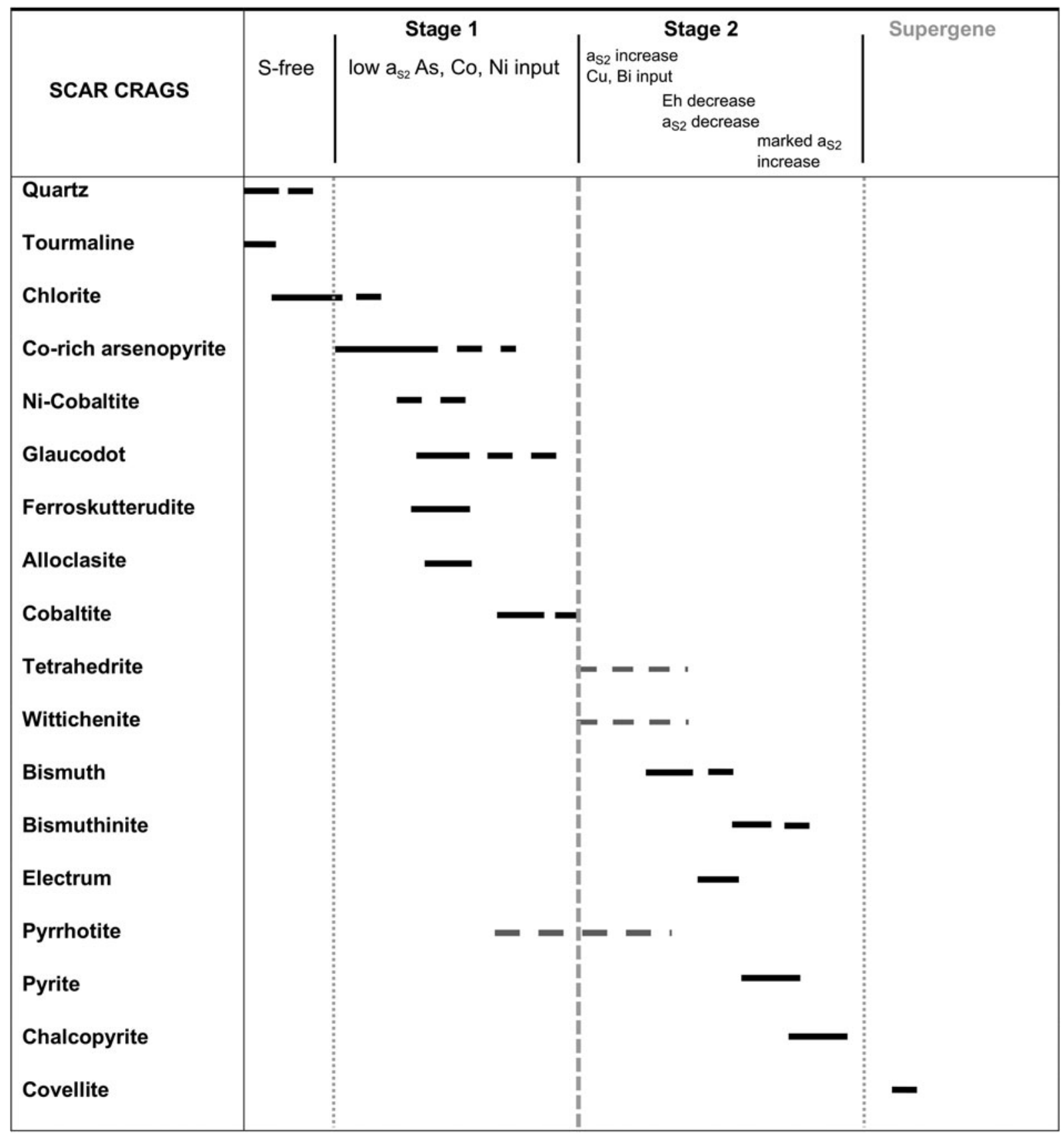

Fig. 11. Paragenetic sequence at Scar Crags.

evolution with time and temperature by Ixer et al. (1979) and Stanley and Vaughan $(1980,1982)$ can be used to coarsely constrain the process that may have governed mineral formation. Using the sulfidation curves from Vaughan and Craig (1978) and Barton and Skinner (1979) (as per Stanley and Vaughan, 1982, Fig. 2) it can be inferred that the precipitation of sulfarsenides and bismuth after pyrite at Dale Head North could be the result of a sudden drop of $a_{\mathrm{S}_{2}}$ ( 2-4 log units), assuming that temperature of the fluids remained nearly constant (Fig. 13). In contrast, the reappearance of pyrite in the late phases of mineral precipitation (second phase of pyrite, Fig. 12) suggests a temperature decrease of several tens of degrees by stage 4 , plus a reduction of $\mathrm{pH}$ to allow marcasite precipitation (Fig. 12). In addition, the formation of pyrite in the late-stage mineralisation at Scar Crags (stage 2, Fig. 11) forces the calculated $\log \left(a_{\mathrm{S}_{2}}\right)$-temperature path to extend to temperatures $<280^{\circ} \mathrm{C}$, thus, suggesting a $\sim 80-90^{\circ} \mathrm{C}$ temperature drop during mineral precipitation from stage 1 to 2 .

\section{Genesis of mineralisation and fluids pathways}

A thorough review of the existing literature indicates the most probable source of the mineralising fluids of Scar Crags and Dale Head North are the rocks of the Borrowdale Volcanic Group (Stanley and Vaughan 1982), though Ixer et al. (1979) suggest the underlying stock intrusion at Causey Pike as the principal 


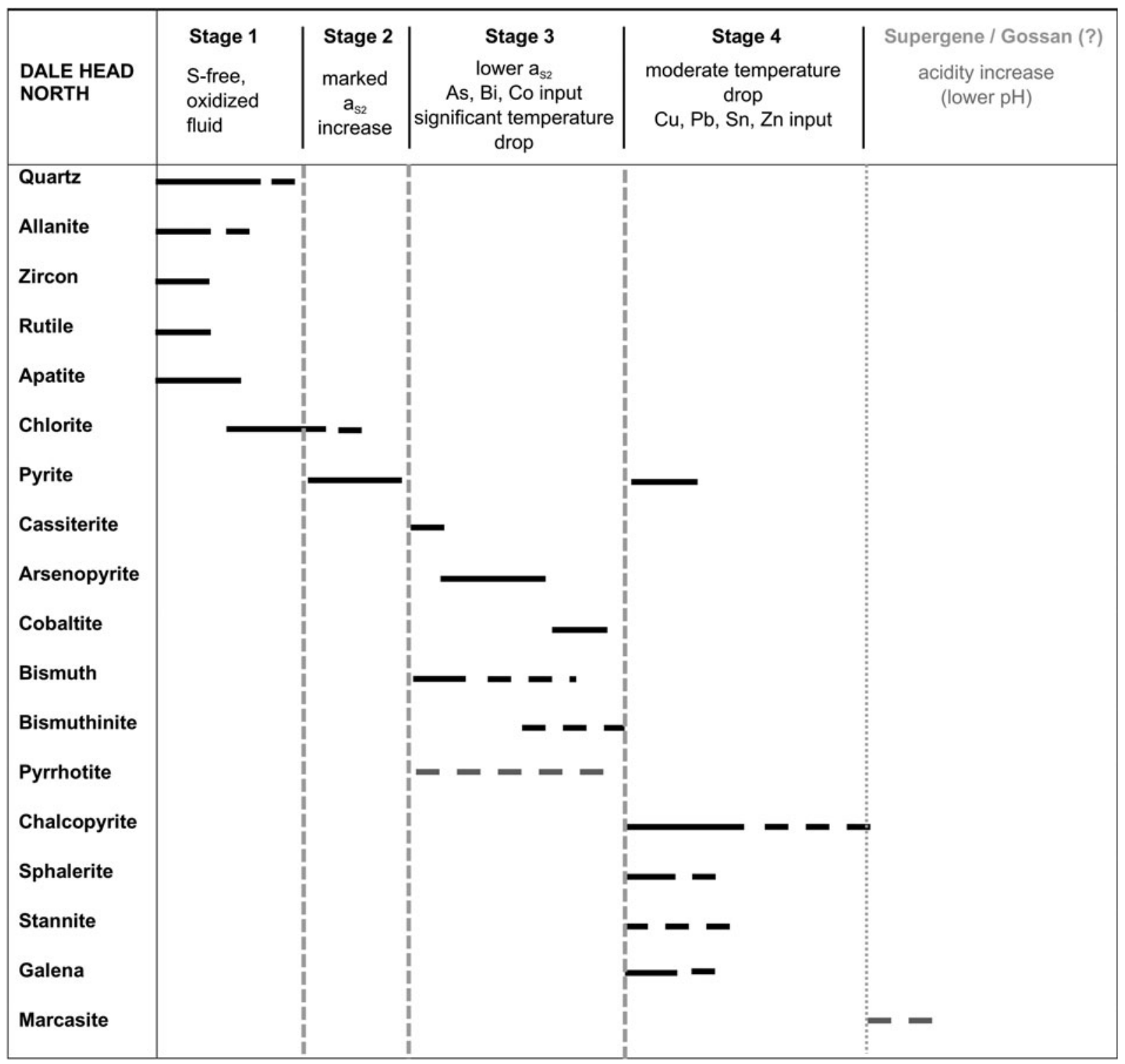

Fig. 12. Paragenetic sequence at Dale Head North.

source. The Skiddaw Group rocks were excluded on the basis that those lithologies would have been deprived of most of their original water by the main metamorphic events of the Caledonian orogeny (Stanley and Vaughan, 1982).

There are two pivotal, though contrasting, features from previous investigations. (1) The suggested net input of multiple elements, such as As, B and $\mathrm{K}$, to induce chemical changes in siltstone and mudstone in the proximity of Scar Crags ('bleached' rocks, metasomatic aureole of Crummock Water; Cooper et al., 1988; Figs 2 and 14a-b). This process is attributed to the action of upward-migrating, magmatic fluids from a concealed intrusion (similar in age to the Shap Granite, Cooper et al., 1988). (2) The nature of mineralising fluids as connate waters forced into strong circulation by the heat flow generated from the intrusion of the Lake District batholith (Stanley and Vaughan 1980). Additionally, Stanley and Vaughan (1980) explain the difference of estimated temperature of mineral precipitation at Scar Crags and Dale Head North by suggesting that Dale Head North veins were emplaced at shallower depth, thus further away from the intrusion. The latter interpretation could be challenged by considering that the topography of the intrusions at Scar Crags and Dale Head North might differ as suggested by Cooper et al. (1988). In this hypothesis Scar Crags would be located on top of a high-level stock-like hypabyssal body (see section 'Mineralisation formation models'; Fig. 14), whereas the intrusives at Dale Head North would be deeper with respect to the level of ore mineral precipitation. In any case, in both scenarios the combination of different distance from intrusions and the lithology of the country rock at the two localities, would have yielded different styles of fluid-rock interaction and mineralisation.

We speculate that at Dale Head North, fluids released by the intrusives followed vein-type emplacement as faulting became the preferred pathway (Fig. 14a). For Scar Crags, it should be noted that the activity of the Causey Pike Fault, crossing through the Scar Crags area, could have controlled the emplacement of the 


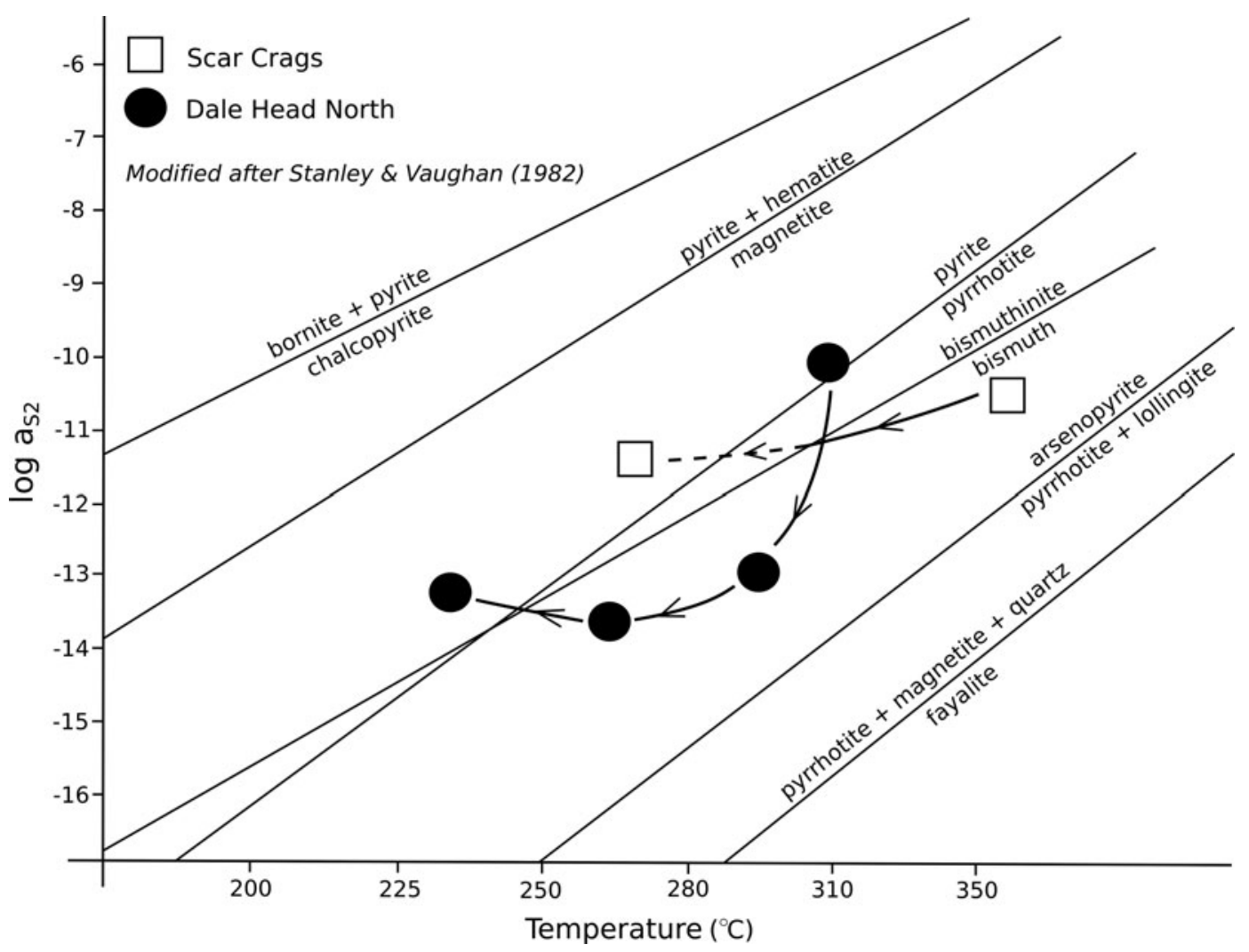

Fig. 13. Simplified $\log a_{S_{2}}$ vs. temperature phase diagram for the mineral precipitation sequence at Scar Crags and Dale Head North (modified after Stanley and Vaughan, 1982). The evolution of temperature and sulfur activity in the two mineralised systems is based on the interpretation of the paragentic sequences as described in section 'Genesis of mineralisation and fluids pathways'.

intrusives (Cooper et al., 1988) and possibly allowed rapid upward migration of large volumes of magmatic fluids. Neither of these early stage events involved sulfur-rich fluids, proven by lack of sulfides during the first stage of Dale Head North mineral precipitation and by the absence of disseminated sulfides in the Crummock Water metasomatic aureole. The sulfarsenides mineralisation (similar at both localities) can be interpreted as a later event, and it is probably the result of contribution from laterstage magmatic fluids (As-Co-Cu-Ni-rich) followed by hydrothermal scavenging of metals $(\mathrm{Bi}, \mathrm{Cu}, \mathrm{Pb}, \mathrm{Sb}, \mathrm{Se}, \mathrm{Te}$ and $\mathrm{Zn})$ as a result of intense fluid circulation through the host rock, both of which accumulated into fault planes and fractures. This hypothesis is in part supported by whole-rock data given by Cooper et al. (1988) indicating loss of $\mathrm{Cu}, \mathrm{Zn}$ and $\mathrm{S}$ (among other elements) in the 'bleached' rocks in comparison to the unaltered protoliths. The hypothesised marked drop in temperature during the later stages of mineral deposition at Dale Head North (see Comparison between mineralisation and with previous findings; Figs 13,14) could be related to waning of the magmatic fluids contribution in favour of relatively cooler circulating host rock-derived fluid, perhaps with mixing of the two fluid types. A decrease of magmatic fluid input could also have triggered a fluid composition shift at Scar Crags (input of $\mathrm{Bi}, \mathrm{Cu}$ and possibly $\mathrm{Ag}, \mathrm{Au}$ ), but a temperature drop was not recorded, presumably due to closer proximity to the intrusives.

The mineralogy and paragenesis of Scar Crags and Dale Head North are similar to those of the world class Bou Azzer cobalt deposits in Morocco. Ahmed et al. (2009) modelled ore precipitation in Bou Azzer as triggered by mixing of magmatic fluids and meteoric waters in a fashion similar to that envisaged for Scar Crags and Dale Head North. Ghandi et al. (2018) described an early Co-bearing sulfarsenide precipitation stage as magmatic waters, followed by later sulfides precipitation from convecting meteoric waters for the Port Radium ore (Northwest Territories, Canada). This is comparable to the process responsible for mineral precipitation in the two localities studied in terms of paragenesis, but we infer that mixing of the fluids is necessary to trigger sulfarsenide deposition (see above in this section and further in 'Mineralisation formation models'). The cobalt-mineral-bearing veins in Bou Azzer, Port Radium, as well as those of numerous other cobalt world-class ore deposits (see table 1 in Markl et al., 2016) all share the common characteristic of carbonates as a principal gangue mineral. The presence of carbonates is ascribed to the input of high-salinity basinal brines, rich in calcium (Ikenne et al., 2020 and references therein) and possibly with hydrocarbons (Markl et al., 2016) that could be the principal responsible for scavenging $\mathrm{Co}, \mathrm{Ni}$, As and other metals from various source rocks. These types of brines do not seem a viable medium for the genesis of Scar Crags and Dale Head North due to the lack of a potential source for these.

Potential sources of $\mathrm{Co}, \mathrm{Ni}, \mathrm{As}$ and $\mathrm{S}$ vary from serpentines (Ahmed et al., 2009, Ikenne et al., 2020) to metasediments and/ or volcano-sedimentary lithologies (Ikenne et al., 2020 and references therein).

A comprehensive definition of the nature of the fluids and the source/s of metals in Scar Crags and Dale Head North exceeds the scope of this investigation, and it might be tackled after fluid inclusions and stable isotope data become available. 

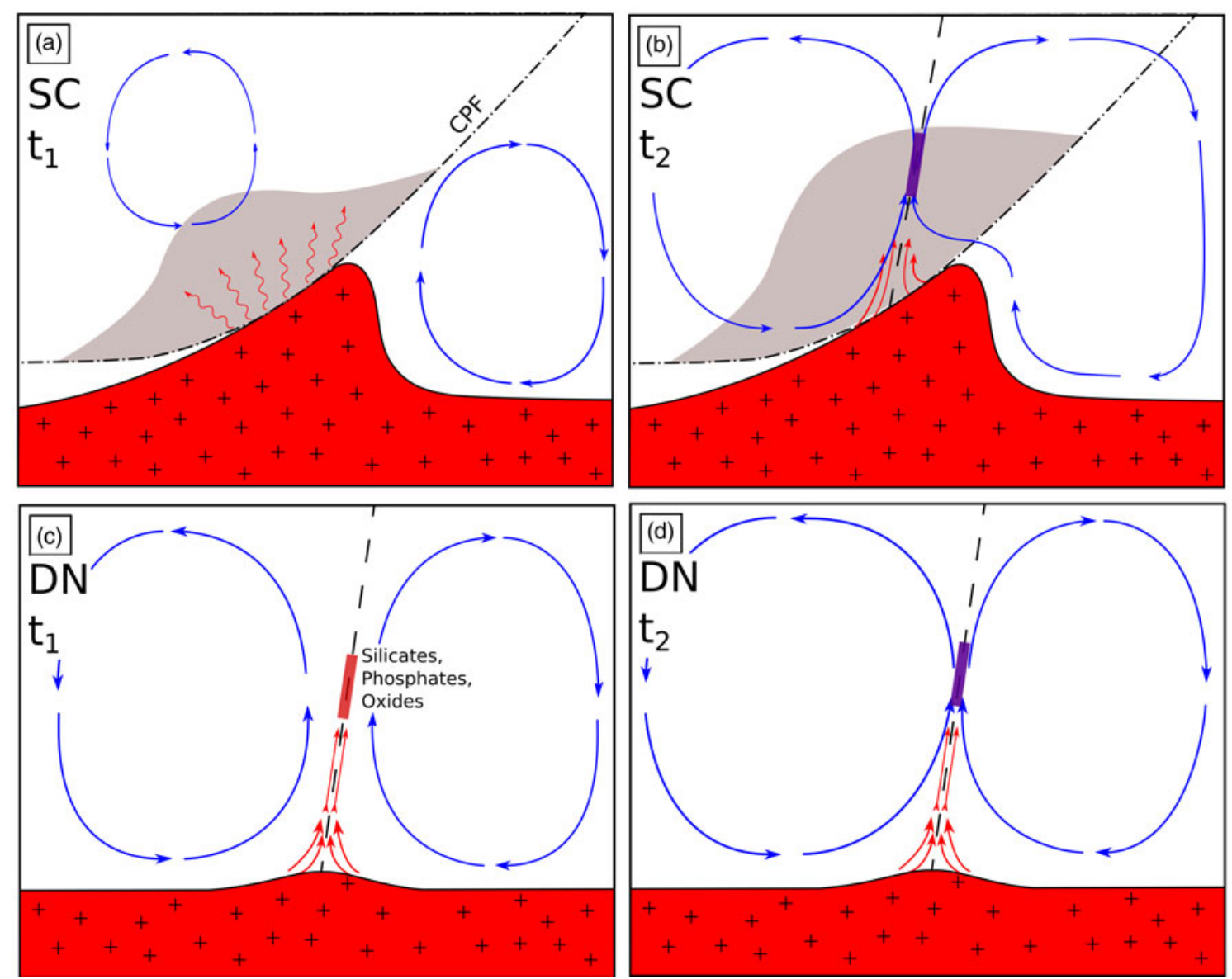

Fig. 14. Schematic illustrating the process of emplacement and genesis of the Scar Crags and Dale Head North mineralisation. (a) Scar Crags: Genesis of a metasomatic aureole (light grey shade) controlled by the Causey Pike Fault. Convection-like circulation of connate and meteoric waters (arrow-headed, blue curves) is driven by the exaggerated geothermal gradient generated by the shallow intrusion. (b) Scar Crags: After the pre-mineralisation stage (panel (a)) a near-vertical fault (probably with a strike-slip movement) develops and becomes a preferred site for accumulation of both magmatic (red colour) and convecting connate/meteoric (blue colour) fluids. These mixed fluids formed the mineralisation of Scar Crags, located on the fault plane itself (purple block). The mineralisation is hosted by 'bleached' rocks (light grey shaded area). (c) Dale Head North: Emplacement of early stage mineralisation (i.e. oxides, phosphates and silicates - red block) via infill on a fault plane. The fault plane becomes the preferred pathway for late-stage magmatic fluids (red colour) resurgence. Convection-like circulation of connate and meteoric waters (arrow-headed, blue curves) is induced by the geothermal gradient generated by the intrusion. (d) Dale Head North: Intense convection of meteoric/connate waters (arrow-headed, blue curves), developed over time, fostering input of these fluids into the fault plane. This yielded a mixed fluids stage of mineral precipitation (purple block). CPF: Causey Pike Fault, DN: Dale Head North, SC: Scar Crags, $t_{1}$ : early stage of mineralisation process, $t_{2}$ : late stage of mineralisation process, dot and dash line indicates thrust fault planes, dashed line indicates strike-slip faults, light grey shaded area represents metasomatised lithologies, red colour with crosses represent intrusive rocks.

\section{Mineralisation formation models}

We suggest a genetic model based on a two-stage process for both localities, as illustrated in Fig. 14.

In the initial stage at Scar Crags, the Causey Pike Fault controlled the genesis of a metasomatic aureole through siltstones and mudstones of the Kirkstile Formation (Stanley and Vaughan 1982; Cooper et al., 1988; Fig. 14a). This is the first phase of the genesis of the mineralised veins (pre-mineralisation). The geometry of the thrust fault plane influenced the emplacement of a concealed intrusive similar in age to the Shap granite (Cooper et al., 1988), creating a domed structure (stock-like intrusion), and enhancing the release of large volumes of late-stage crystallisation fluids from the intrusion into the overlying, relatively porous sedimentary rocks. Convection-like circulation of connate and meteoric waters was driven by the exaggerated geothermal gradient generated by the shallow intrusion (Ixer et al., 1979). The second stage of mineralisation at Scar Crags was driven by the development of a near-vertical fault (probably with a strike-slip movement) becoming the preferred site for accumulation of both magmatic and convecting connate/meteoric fluids (Fig. 14b). These mixed fluids formed the mineralisation of Scar Crags, located on the fault plane itself. The metasomatic aureole has expanded through time (Fig. 1); thus, the mineralisation is hosted by 'bleached' rocks (Stanley and Vaughan 1982; see section 'Geology of the areas' in 'Results').

At Dale Head North the emplacement of the early stage mineralisation (i.e. oxides, phosphate and silicates) occurred via fluid infill on a fault plane that extended downwards to the Lake District batholith or another concealed, yet smaller, intrusive body (Fig. 14c). The fault plane became the preferred pathway for late-stage magmatic fluids resurgence. Convection-like circulation of connate and meteoric waters occurred due to the geothermal gradient generated by the intrusion, yet, this is weaker than at Scar Crags. This is a consequence of the lower porosity of the sedimentary and volcanic rocks overlying the batholith at Dale Head North and of the greater depth of the intrusives with respect 
to Scar Crags (Ixer et al., 1979). The development and the expansion of intense convection of meteoric/connate waters over time (later stage, Fig. 14d) resulted in a major input of these fluids into the fault plane. The latter fluids bring metals (As, Co, Bi, $\mathrm{Cu}, \mathrm{Ni}, \mathrm{Pb}, \mathrm{Sn}$ and $\mathrm{Zn}$ ), additional to those derived from the intrusives, into the Dale Head North mineralised veins, finally yielding a mixed fluid stage of mineral precipitation, similar to that recorded at Scar Crags.

\section{Final remarks}

With the combination of techniques used in this investigation together with analysis and discussion of new data in the light of previous studies of the As- $\mathrm{Bi}-\mathrm{Co}-\mathrm{Cu}$ mineralisation of Scar Crags and Dale Head North it was possible to establish that: (1) the emplacement of Scar Crags mineralised veins exploited the space created by a NE-SW trending strike-slip fault; (2) sulfarsenides in both localities are solid solutions of $\mathrm{Fe}, \mathrm{Co}$ and $\mathrm{Ni}$ endmembers; (3) the arsenopyrite geothermometer is not applicable to either of the mineral assemblages; and (4) an early stage of mineral precipitation from a S-poor fluid is recorded at Dale Head North.

It is worth noting that cobalt- and nickel-bearing arsenopyrite is present in both localities, and it appears to mark the start of the deposition of cobalt minerals. Therefore, we hypothesise that it could be developed further as a first-pass fingerprint of cobaltbearing mineral formation. We suggest that further investigation is needed to ascertain whether finding Co- and/or Ni-bearing arsenopyrite during fieldwork (e.g. recording measurable amounts of $\mathrm{Co}$ and $\mathrm{Ni}$ with portable X-ray fluorescence or laserinduced breakdown spectroscopy on larger arsenopyrite crystals), could be used to aid discrimination of a potential $\mathrm{Co}-\mathrm{Ni}$ suite of alloclasite, cobaltite and glaucodot.

In order to expand the conclusions of this investigation, it is necessary to study several more of the vein-type deposits of the Lake District region, focusing on those emplaced in the early Devonian, especially if associated with As-bearing mineralisation (e.g. Carrock End, Coniston veins, Greenburn, Long Crag, Ulpha, etc.; Stanley and Vaughan, 1982). Moreover, to best constrain the source of the mineralising fluids and of the metals it is recommended to obtain stable isotopic data for hydrogen and oxygen of gangue minerals, and for sulfur of ore minerals. Finally, a comprehensive study of the primary fluid inclusions of hydrothermally grown quartz from the mineralised veins is necessary to assess emplacement temperature of the fluids, their salinity, and to estimate the broad chemistry of the fluids.

\begin{abstract}
Acknowledgements. The authors of this contribution thank James Darling and Sean McCleanaghan for valuable suggestions that helped improve the quality of the study. GS thanks Luca Caricchi and Martin Robyr for help and support with EMPA. GS and NW thank Neil Holloway for speedy preparation of high-quality polished blocks. NW and AE thank the Research Committee of the Earth Sciences Department of Royal Holloway University of London for a generous contribution towards the analytical costs sustained for this project. The authors thank an anonymous reviewer, Dr Moha Ikenne and Dr Eimear Deady for useful comments that helped improve the manuscript. SCJ is supported by iCRAG under the Science Foundation Ireland, EU Regional Development Fund and industry partners (13/RC/ 2092), as well as SFI research grant $16 / \mathrm{RP} / 3849$. AE is supported by the Reid doctoral scholarship of Royal Holloway University of London.
\end{abstract}

Supplementary material. To view supplementary material for this article, please visit https://doi.org/10.1180/mgm.2021.22

\section{References}

Ahmed A.H., Shoji A. and Ikenne M. (2009) Mineralogy and Paragenesis of the Co-Ni Arsenide Ores of Bou Azzer, Anti-Atlas, Morocco. Economic Geology, 104, 249-266.

Alves D.P., Blagoeva D., Pavel C. and Arvanitidis N. (2018) Cobalt: Demand-Supply Balances in the Transition to Electric Mobility. EUR 29381 EN, Publications Office of the European Union, Luxembourg, 2018, https://doi.org/10.2760/97710,JRC112285.

Anderton R., Bridges P., Leeder M. and Sellwood B. (1995) A Dynamic Stratigraphy of the British Isles. Chapman and Hall, London, pp. 39-66.

Barton P.B. and Skinner B.J. (1979) Sulfide mineral stabilities. Pp. 278-403 in: Geochemistry of Hydrothermal Ore Deposits (H.L. Barnes, editor). Wiley and Sons, New York.

Bennison G. and Wright A. (1969) The Geological History of the British Isles. Edward Arnold Ltd, London, UK, pp. 71-159.

California Institute of Technology (2011) Critical Metals for Sustainable Energy Applications. Resnick Institute Report, California, USA, pp. 22-31.

Cooper D., Lee M., Fortey N., Cooper A., Rundle C., Webb B. and Allen P. (1988) The Crummock Water aureole: a zone of metasomatism and source of ore metals in the English Lake District. Journal of the Geological Society, $145,523-540$

Department of Energy of the United States of America (2011) Critical Materials Strategy.

Dewey J. (1969) Evolution of the Appalachian-Caledonian orogen. Nature, 222, 124-129.

European Commission (2020) Study on the EU's list of Critical Raw Materials Final Report (2020). https://doi.org/10.2873/11619

Firman R. and Lee M. (1986) The age and structure of the concealed English Lake district batholith and its probable influence on subsequent sedimentation, tectonics and mineralisation. Pp. 117-127 in: Geology in the Real World Kingsley Dunham Volume. Institution of Mining and Metallurgy London.

Ghandi S.S., Potter E.G. and Fayek M. (2018) New constraints on genesis of the polymetallic veins at Port Radium, Great Bear Lake, Northwest Canadian Shield. Ore Geology Reviews, 96, 28-47.

Halls C. and Stumpfl E.F. (1972) The five-element (Ag-Co-Bi-Ni-As) vein deposit - A critical appraisal of the geochemical environments in which it occurs and of the theories affecting its origin. Pp. 540 in: Proceedings, $24^{\text {th }}$ International Geological Congress, Montreal, Sec. 4.

Hunter A. and Easterbrook G. (2004) The Geological History of the British Isles. The Alden Group, Oxford, UK, pp. 41-59.

Ikenne M., Souhassou M. Saintilan N.J., Karfal A., Hassani A.E.L., Moundi Y., Ousbih M., Ezzghoudi M., Zouhir M. and Maacha L. (2020) Cobalt-nickelcopper arsenide, sulfarsenide and sulfide mineralization in the Bou Azzer window, Anti-Atlas, Morocco: one century of multi-disciplinary and geological investigations, mineral exploration and mining. In: Mineralization and Sustainable Development in the West African Craton: From Field Observations to Modelling (T. Aifa, editor). Geological Society, London, Special Publications, 502, https://doi.org/10.1144/SP502-2019-132

Ixer R., Stanley C. and Vaughan D. (1979) Cobalt-, nickel-, and iron-bearing sulfarsenides from the North of England. Mineralogical Magazine, 43, 389395.

Kissin S.A. (1992) Five-element (Ni-Co-As-Ag-Bi) veins. Geoscience Canada, $19,113-124$.

Kretschmar U. and Scott S. (1976) Phase relations involving arsenopyrite in the system $\mathrm{Fe}-\mathrm{As}-\mathrm{S}$ and their application. The Canadian Mineralogist, 14, 364-386.

Le Pape P., Blanchard M., Brest J., Boulliard J-C., Ikogou M., Stetten L., Wang S., Landrot G. and Morin G. (2016) Arsenic incorporation in pyrite at ambient temperature at both tetrahedral S-I and octahedral Fe+II sites: evidence from EXAFS-DFT analysis. Environmental Science \& Technology, 51, https://doi.org/10.1021/acs.est.6b03502.

Lowell G.R. and Gasparrini C. (1982) Composition of arsenopyrite from topaz greisen veins in southeastern Missouri. Mineralium Deposita, 17, 229-238.

Markl G., Burisch B. and Neumann U. (2016) Natural fracking and the genesis of five-element veins. Mineralium Deposita, 51, 703-712.

Millward D. (2002) Early Palaeozoic magmatism in the English Lake District. Proceedings of the Yorkshire Geological Society, 54, 65-93. 
Mosely F. (1978) The Geology of the Lake District. W.S. Maney and Sons Limited, Leeds, UK, pp. 79-164.

Moss R.L., Tzimas E., Kara H., Willis P. and Kooroshy J. (2011) Critical metals in the path towards the decarbonisation of the EU energy sector. Assessing rare metals as supply-chain bottlenecks in low-carbon energy technologies. Critical Metals in Strategic Energy Technologies. Joint Research Centre (JRC) - Institute for Energy and Transport, https://doi.org/10.2790/46338

Petruk W., Harris D.C. and Stewart J.M. (1971) Characteristics of the arsenides, sulfarsenides, and antimonides. The Canadian Mineralogist, 11, 150-186.

Shore M. and Fowler A.D. (1996) Oscillatory zoning in minerals; a common phenomenon. The Canadian Mineralogist, 34, 1111-1126.

Stanley C. and Vaughan D. (1980) Interpretative studies of copper mineralization to the south of Keswick, England. Transactions of the Institution of Mining and Metallurgy, 89, 25-30.
Stanley C. and Vaughan D. (1982) Copper, lead, zinc and cobalt mineralization in the English Lake District: classification, conditions of formation and genesis. Journal of the Geological Society, 139, 569-579.

Stone P., Millward D Young B., Merritt J., Clarke S., McCormack M. and Lawrence D. (2010) British Regional Geology: Northern England. (D. Millward., S.G. Molyneux. and J.E. Thomas, editors). BGS, Keyworth, Nottingham, UK.

Strens R.G. (1962) The Geology of The Borrowdale-Honister District (Cumberland), with Special Reference to the Mineralization. Unpublished $\mathrm{PhD}$ Theses, University of Nottingham, UK

Vaughan D.J. and Craig J. (1978) Mineral Chemistry of Metal Sulfides. Cambridge University Press, UK.

Vesselinov I. and Kerestedjian T.N. (1995) Kinetic aspects of sector zoning in arsenopyrite: a case study. Mineralogy and Petrology, 52, 85-106. 